\title{
Winter Rain versus Snow in Headwater Catchments: Responses of an Unconfined Pumice Aquifer, South-Central Oregon, USA
}

\author{
Michael L. Cummings*, David A. Eibert \\ Department of Geology, Portland State University, Portland, Oregon \\ Email: ${ }^{\star}$ cumminm@pdx.edu
}

How to cite this paper: Cummings, M.L. and Eibert, D.A. (2018) Winter Rain versus Snow in Headwater Catchments: Responses of an Unconfined Pumice Aquifer, SouthCentral Oregon, USA. Journal of Water Resource and Protection, 10, 461-492. https://doi.org/10.4236/jwarp.2018.104025

Received: March 9, 2018

Accepted: April 27, 2018

Published: April 30, 2018

Copyright (c) 2018 by authors and Scientific Research Publishing Inc. This work is licensed under the Creative Commons Attribution International License (CC BY 4.0).

http://creativecommons.org/licenses/by/4.0/

\begin{abstract}
Winter precipitation in two headwaters catchments (elevation $\sim 1600 \mathrm{~m}$ ) in the rain shadow of the Cascades volcanic arc in south-central Oregon normally falls as snow. However, in water year 2015, winter precipitation fell mainly as rain. An eight year study of the unconfined pumice aquifer allowed inter-annual comparison of groundwater recharge during the freshet and discharge during the growing season. During these water years precipitation ranged from 67\% (WY2014) to 132\% (WY2017) of the 30 year average, and included the rain dominated winter of WY2015 when precipitation during the water year was $98 \%$ of the 30 year average. Change in storage in the pumice aquifer was estimated from thickness of the pumice deposit and depth to water table from the ground surface. Measurements were made where 1) the pumice aquifer was exposed at the surface; 2 ) where the aquifer was partially eroded and overlain by either alluvium or lacustrine glassy silt to fine sand; 3 ) fens where the partially eroded aquifer was overlain by peat; and 4) monitoring wells drilled through the pumice aquifer into bedrock. In all settings, groundwater storage in the pumice aquifer following the rain-dominated winter of WY2015 was similar or less than storage following the drought of WY2014 when winter precipitation fell as snow. Storage at the end of WY2014 and WY2015 was the least observed in the eight year study. Winter-time rain during WY2015 produced runoff rather than storage in snow pack. Runoff was conveyed from the catchments by flow in stream reaches normally dry from late summer through the winter months. Rain-dominated winter precipitation stresses the perched pumice aquifer. Winter storms starting as rain and turning late to snow and ground-freezing temperatures lead to runoff during the next rain-dominated precipitation event. These patterns produced stream flow in channels that are commonly dry during the winter, reduced near-surface groundwater storage in the pumice aquifer, muted springtime
\end{abstract}


freshet, and stressing of groundwater-dependent ecosystems, forage in meadows, and forest health.

\section{Keywords}

Unconfined Pumice Aquifer, Headwater Catchment, Winter Precipitation

\section{Introduction}

The accumulation of snow during the winter, release of melt water during the spring freshet, and low, scattered precipitation during the summer, characterizes the hydrologic regime in watersheds throughout western North America. Inter-annual variations in these patterns are mirrored in the predicted yield of water from higher elevation catchments to meet demands for wildlife, agriculture, recreation, and city water supplies [1]. The inter-annual variations provide potential scenarios of how catchments may respond to various models of climate change (e.g. [2] [3] [4]). In the Pacific Northwest, small changes in annual precipitation in higher elevation catchments are expected to be associated with change from snow-dominated to snow and rain-dominated to rain-dominated precipitation regimes [2] [3] [4] [5]. How these changes impact groundwater storage, particularly near-surface storage in the rooted zone, has received less attention. Garcia and Tague [6] examined the relation between subsurface storage and drainage of winter precipitation and the availability of water to support plant growth during the summer months in five headwater catchments in the western United States (western Oregon Cascades, central Colorado Rocky Mountains, and central California Sierras). The study described in our paper examines storage of winter precipitation in an unconfined pumice aquifer and how the aquifer responded to snow-dominated versus rain-dominated winter precipitation.

The unconfined pumice aquifer in the Walker Rim study area is an important source of near-surface groundwater in south-central Oregon in the rain shadow of the Cascades Range (Figure 1). Within the Walker Rim study area the upper Jack Creek catchment and neighboring Round Meadow/Sellers Marsh closed-basin catchment are distinctive due to the perched aquifer hosted in Plinian pumice fall from the cataclysmic eruption of Mount Mazama in the Cascades volcanic arc 7700 years B.P. [7]. In the simplest interpretation, the perched aquifer recharges during the spring snow melt and discharges primarily by evapotranspiration during the growing season. The period of observation (water year (WY) WY2010 to WY2017) includes water years characterized by annual precipitation that was 132 percent of the 30 year average and a drought year characterized by the third lowest precipitation during 44 years of record at the Chemult Alternate SNOTEL Site (http://www.wcc.nrcs.usda.gov/nwcc/site?sitenum=395). However, WY2010 to WY2014, WY2016, and WY2017 were characterized by accumulation 


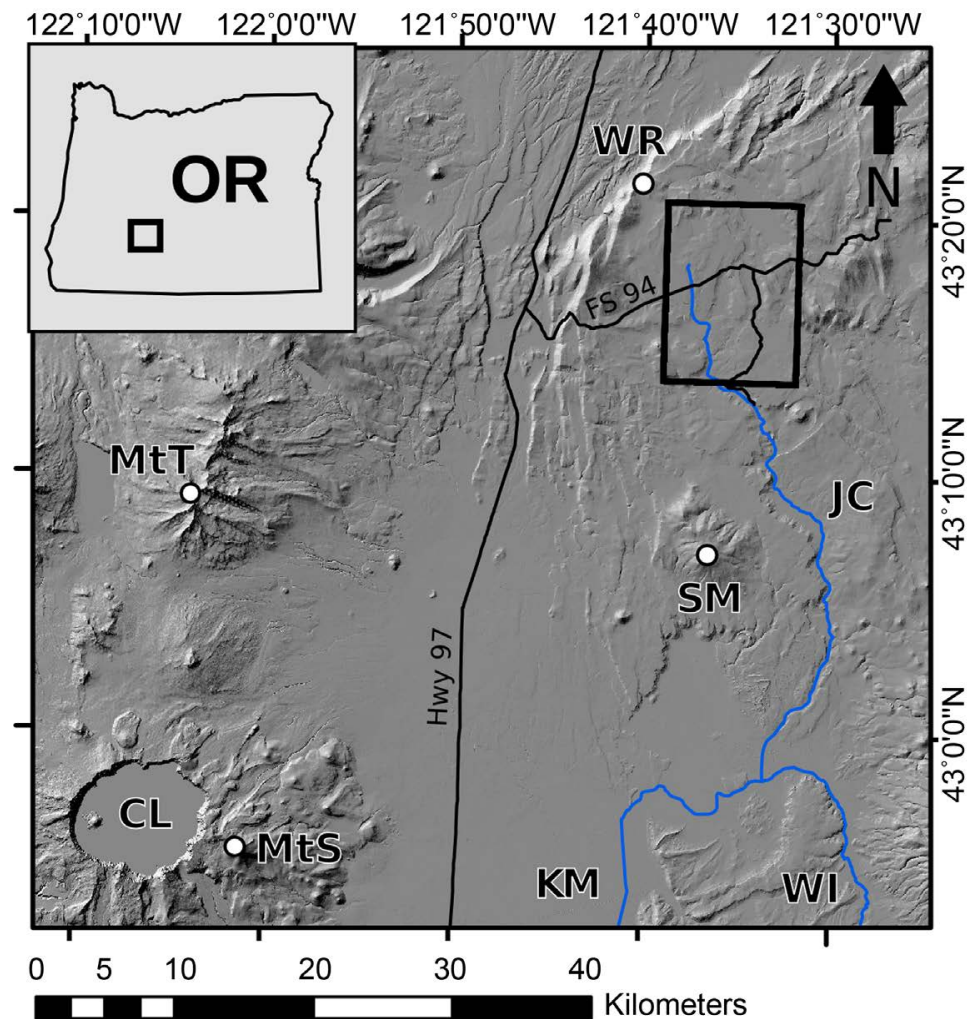

Figure 1. Location map of the Walker Rim study area (black rectangle) which contains the upper Jack Creek and Round Meadow/Sellers Marsh catchments. CL: Mount Mazama (aka Crater Lake), MtS: Mt Scott, MtT: Mt Thielsen, KM: Klamath Marsh, WI: Williamson River, SM: Sugarpine Mountain, JC: Jack Creek, WR: Walker Rim.

of snow pack during the fall and winter while in WY2015 winter precipitation fell primarily as rain. The primary questions addressed in this paper are: What was the response of the pumice aquifer to rain-dominated winter precipitation? What does this response suggest about groundwater availability in this area under changing climate conditions?

\section{Characteristics of Catchments}

The two forested catchments considered in this study lie at elevations greater than 1590 m within the Walker Rim study area (Figure 1). The first catchment, the upper Jack Creek catchment (Figure 2), lies at elevations between $1590 \mathrm{~m}$ and $2159 \mathrm{~m}$. However, most of the catchment lies between $1590 \mathrm{~m}$ and $1760 \mathrm{~m}$. The greatest local relief and highest elevation are associated with the east sloping flanks of fault blocks that form Walker Rim and include Walker Mountain which rises to $2159 \mathrm{~m}$. The lack of an east-flowing drainage network and few indications of groundwater storage in the pumice deposit suggest this feature contributes little to the pumice aquifer in the upper Jack Creek catchment. The area of the upper Jack Creek catchment is $125 \mathrm{~km}^{2}$.

The second catchment, the Round Meadow/Sellers Marsh catchment (Figure 2), lies at elevations between $1654 \mathrm{~m}$ and $1954 \mathrm{~m}$ (Marmot Butte). However, 


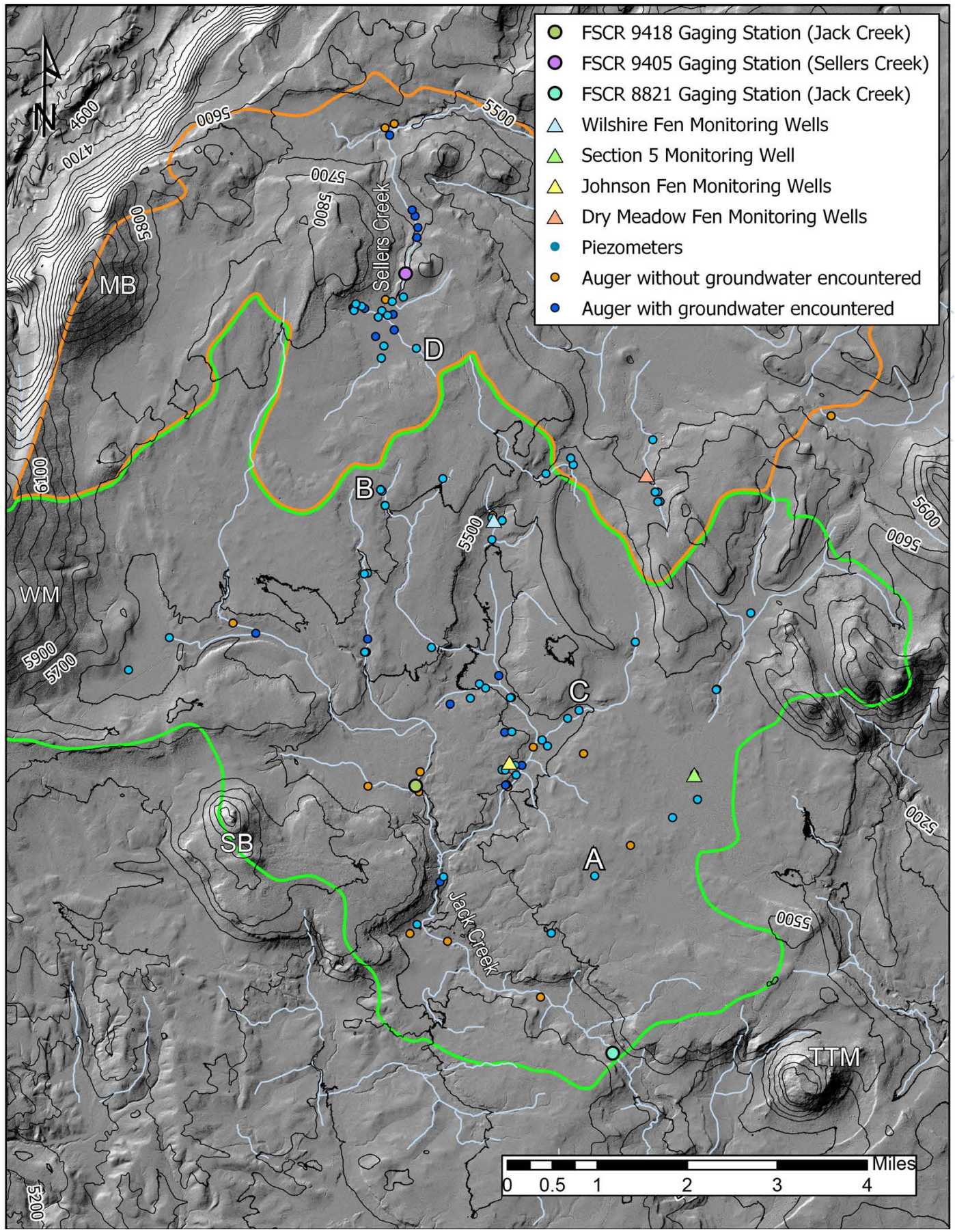

Figure 2. Upper Jack Creek (green line) and Round Meadow/Sellers Marsh (orange line) catchments. A culvert passing beneath Forest Service connector road (FSCR 8821, gaging location FSCR 8821) is set as the outlet from the upper Jack Creek catchment. The Round Meadow/Sellers Marsh catchment is a closed basin. Blue dots indicate the locations of piezometers used in this study. Hydrographs for piezometers at A, B, C, and D are presented below in Figures 3-6, respectively. Dark blue dots indicate locations of auger holes where the pumice aquifer was partially saturated, but a piezometer was not installed. Orange dots indicate auger holes where groundwater was not present in the pumice deposit. Triangles indicate locations of monitoring wells were drilled through the pumice deposit into bedrock at three fens (Dry Meadow, Wilshire, and Johnson) and a non-fen site. $\mathrm{WM}=$ Walker Mountain, $\mathrm{MB}=$ Marmot Butte, $\mathrm{SB}=$ Skookum Butte, and $\mathrm{TTM}=$ Tea Table Mountain. 
most of the catchment lies between 1654 and $1720 \mathrm{~m}$. This closed basin lies between the Deschutes River basin to the north and the Klamath River basin to the south. A ditch connects Sellers Marsh, the lowest elevation wetland in the catchment, and the upper Deschutes River basin; however, evidence of flow in this ditch was not identified during the period of study. The area of the Round Meadow/Sellers Marsh catchment is $64 \mathrm{~km}^{2}$.

The unifying characteristic of the two headwater catchments is the $2.7 \mathrm{~m}$ to $3.0 \mathrm{~m}$ thick blanket of Plinian pumice fall. The pumice blanket was deposited during the cataclysmic eruption of Mount Mazama in the Cascades volcanic arc at 7700 yr. B.P. [7] [8]. Except for local modifications by fluvial and lacustrine processes after the eruption, the pumice blanket is largely preserved and hosts the unconfined, perched, near-surface aquifer in these catchments. The pumice deposit is divided into a lapilli-dominated lower unit $(\sim 1.6 \mathrm{~m})$ and a poorly sorted, coarse-grained lapilli to block upper unit $(\sim 1.2 \mathrm{~m})$.

The unconfined pumice aquifer presents an opportunity to examine groundwater response to inter-annual variations in the form and amount of winter precipitation. The following characteristics of the aquifer support this evaluation. 1) The pumice blanket was laterally uniform with regard to grain size, stratigraphy, and thickness at the scale of the catchments. 2) The aquifer was hosted in deposits that were exposed at the surface and in most areas were capped by excessively drained soil formed from pumice parent material. 3) Groundwater flow paths within the pumice blanket were controlled by low-relief pre-eruption topography. Disruptions of the pumice aquifer occurred where post-eruption shallow lakes and streams reworked the upper part of the pumice deposit, where iron oxide precipitation has reduced permeability within the aquifer, and where streams have eroded through the pumice deposit to the pre-eruption surface [9] [10].

\section{Data Sources}

Groundwater data were gathered from 22 nested piezometers installed by The Nature Conservancy and Fremont-Winema National Forest at three fens [9] [11], clusters of three monitoring wells screened at different depths at these fens and a single, isolated monitoring well screened to a depth of $15 \mathrm{~m} \mathrm{[12],} \mathrm{and} 67$ single piezometers (commonly $2 \mathrm{~m}$ deep) installed in holes hand augered to determine stratigraphy of alluvial, lacustrine, and pumice deposits. These data were grouped into four categories: 1) piezometers where the pumice deposit was unconfined and exposed at the surface; 2) piezometers screened in the partially eroded pumice aquifer where it was variably confined by alluvial or lacustrine deposits; 3) fens where the pumice aquifer was confined by peat; and 4) monitoring wells completed in underlying bedrock units.

From WY2011 through WY2015 and WY2017, depth to water table was measured between 1-June and 4-June (herein referred to as 1-June) and at the end of the water year (late September) or early in the next water year (October). In addition, depth to water table was measured during the growing season at ir- 
regular intervals. The depth to water table was compared to the thickness of the Plinian pumice fall and, where present, overlying water-lain deposits. Thicknesses of the pumice deposit were determined from auger holes that penetrated the lower contact or were estimated on the basis of the internal stratigraphy of the pumice deposit where the auger hole stopped short of the lower contact. From these data the saturated thickness of the pumice aquifer and changes in storage were estimated.

Air temperature and dew point were measured at least every 60 minutes at 1.8 $\mathrm{m}$ above ground surface, and $50 \mathrm{~cm}$ and $95 \mathrm{~cm}$ below ground surface in the upper Jack Creek catchment at an elevation of $1642 \mathrm{~m}$. Records are available from 10-July-2010. Sensors used for these measurements were Hobo U23 Pro v2 temperature/relative humidity data loggers. The instrumented site was in a stand of Lodgepole pine trees in mottled shade. Precipitation data were available for the Chemult Alternate SNOTEL Site since WY1981

(http://www.wcc.nrcs.usda.gov/nwcc/site?sitenum=395). The elevation of this site is $1478 \mathrm{~m}$, approximately 100 to $300 \mathrm{~m}$ lower than elevations in the study area. The SNOTEL Site is located within 12 to $18 \mathrm{~km}$ of most sites in the upper Jack Creek and Round Meadow/Sellers Marsh catchments.

\section{Results}

Groundwater in the pumice aquifer resides in two distinctly different settings: 1) in pore spaces between pumice grains and 2) in vesicles within pumice grains. Groundwater within the pore spaces between pumice grains moves freely. Weatherford and Cummings [10] used pressure transducers to demonstrate the isotropic character of the pumice aquifer where it is comprised of undisturbed Plinian fall. The spacing between pressure transducers was $400 \mathrm{~m}$. Over a period of 106 days the greatest percent difference in change at each transducer for every 30 minute interval was $0.057 \%$ [13]. The second setting for groundwater is within pumice grains. Klug et al. [14] determined the physical properties of pumice from the Plinian pumice fall near the source, Mt. Mazama. The bulk vesicularity of pumice clasts was between 75 and 88 percent and clasts had high pore interconnectivity ( $>90$ vol. \%). Because of these properties, saturated pumice grains are predominantly water. However, neither the movement of water among vesicles within pumice clasts nor between vesicles in pumice grains and surrounding intergranular pore space are understood. Under conditions of a receding water table, vesicles in pumice grains may remain saturated above the water table. Likewise, under conditions of a rising water table pumice grains may remain unsaturated below the water table.

The annual recession of the water table between 1-June and the end of the water year was approximated as linear based on field measurements from ground surface to water table. The slope of the line was determined for each water year and where field measurements for 1-June or September 30 data were not available. Depth was estimated from the linear relation determined from availa- 
ble field data. 1-June was selected for scheduling convenience for field work, field conditions that allowed access throughout the piezometer network, early timing in the growing season at this elevation, and precipitation patterns associated with the summer (isolated showers with little impact on recharge of the aquifer). Earlier access was possible inWY2014 (19-20-April) and WY2015 (7-March and 18-19-April) because of low snow accumulation during the winter. In some settings, these pre-1-June measurements did not fall on the linear trend that characterized recession of the water table between 1-June and the end of the water year. The differences were interpreted to reflect incomplete adjustments of the groundwater system relative to the freshet-related time of recharge. Likewise, late October measurements deviated from the linear trend in WY2015 when the onset of widespread fall precipitation occurred before final field measurements were performed.

\subsection{Piezometers Where the Unconfined Pumice Aquifer Was Exposed at the Surface}

Relatively few auger holes drilled where the Plinian pumice fall was exposed at the surface encountered a water table. At the eleven sites where groundwater was detected, open-ended PVC pipes (244 cm lengths) with slot cuts were inserted in the auger holes. At these eleven sites at least some of the upper pumice unit had been eroded.

The Forest Service local road 510 (FSLR 510) piezometer (A on Figure 2) was selected to represent this group because the site was located 1) in an area of low local relief (approximately $8 \mathrm{~m}$ within a circle with $1 \mathrm{~km}$ radius centered on the piezometer); 2) excessively drained soil from pumice parent material; 3) pumice thickness of $229 \mathrm{~cm}$; and 4) the auger hole penetrated the underlying paleosol (8 $\mathrm{cm}$ ) before encountering olivine basalt bedrock.

The hydrograph for the FSLR 510 site is presented in Figure 3. Table 1 presents precipitation data for the Chemult Alternate SNOTEL Site for the same time span. This table also includes the snow-water equivalent (SWE) on 1-April, total precipitation received by 1-April, and the percent of the water year precipitation received by 1-April. On 1-June in two years (WY2011 and WY2012, Figure 3), years when annual precipitation exceeded the 30-year average, SWE was nearly $20 \mathrm{~cm}$ on 1 -April, and more than $80 \%$ of the total precipitation had fallen by 1-April (Table 1), the water table was nearer surface than in two years (WY2013 and WY2014) when the annual precipitation was less than the 30-year average, SWE on 1-April was zero, and less than $80 \%$ of annual precipitation was received before 1-April. For purposes of comparison, WY2011 and WY2012 are herein called "wet" years and WY2013 and WY2014 are "dry" years. WY2015, the year when winter precipitation fell mainly as rain, the annual precipitation amount and percent of precipitation received by 1-April followed the "wet" year pattern, but depth to water table on 1-June and SWE on 1-April followed "dry" year patterns. WY2016 and WY2017, years of above average snow-dominated 
FSLR 510 Piezometer

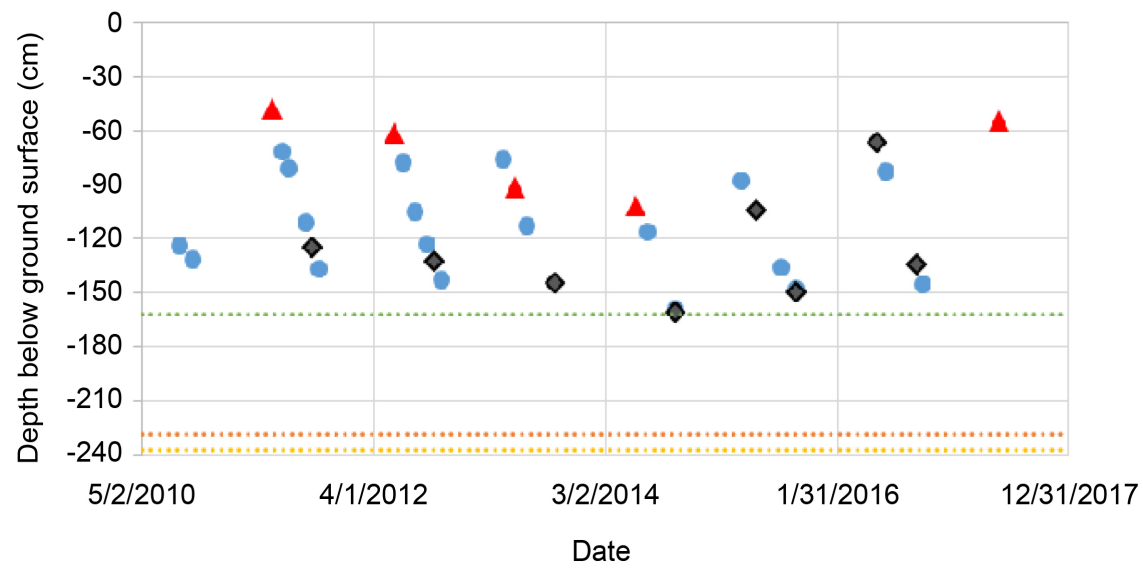

Figure 3. Depth to water table from ground surface for piezometer located at FSLR 510 (Zone 10, 0615707E, 4788841N). Red triangles are field-measurement depths made between 1-June and 4-June of each water year. Black diamonds are estimated depth to water table on 1-June or 30-September of each water year. Blue dots are measurements made on specific dates. Auger hole was $237 \mathrm{~cm}$ deep (yellow dotted line) with piezometer open to $162 \mathrm{~cm}$ (green dotted line). The depth to the contact between pumice and pre-eruption surface (orange dotted line) was $229 \mathrm{~cm}$. The piezometer was monitored from 24-August-2010 to 4-June-2017.

Table 1. Total annual precipitation for the Chemult Alternate SNOTEL Site (Station 395) for WY2010 through WY2017 (http://www.wcc.nrcs.usda.gov/nwcc/site?sitenum=395). SWE is snow water equivalent.

\begin{tabular}{ccccc}
\hline Water year & $\begin{array}{c}\text { Total precipitation } \\
(\mathrm{cm})\end{array}$ & $\begin{array}{c}\text { April 1 SWE } \\
(\mathrm{cm})\end{array}$ & $\begin{array}{c}\text { April 1 total } \\
\text { precipitation } \\
(\mathrm{cm})\end{array}$ & $\begin{array}{c}\text { \% of water year } \\
\text { precipitation by } \\
\text { April 1 }\end{array}$ \\
\hline 2010 & 60.2 & 6.4 & 41.4 & 69 \\
2011 & 82.6 & 28.4 & 67.6 & 82 \\
2012 & 71.9 & 19.3 & 60.4 & 84 \\
2013 & 62.0 & 0.0 & 46.2 & 74 \\
2014 & 46.7 & 0.0 & 36.8 & 79 \\
2015 & 68.3 & 0.0 & 51.6 & 76 \\
2016 & 78.2 & 22.9 & 71.9 & 92 \\
2017 & 92.2 & 23.6 & 80.3 & 87 \\
30 -year & 69.8 & & & \\
average & & & & \\
\hline
\end{tabular}

winter precipitation, over $20 \mathrm{~cm}$ of SWE on 1-April, and greater than $80 \%$ of annual precipitation received by 1-April, behave similar to the "wet" years.

The recession rate of the water table in $\mathrm{cm} /$ day between 1 -June and 30 -September was greater in water years when the water table on 1-June was within the main rooted zone. In contrast the recession rate was lower in water years when the water table was below the main rooted zone on 1-June. Higher 
recession rates (e.g. $0.61 \mathrm{~cm} /$ day in WY2011 when water table was $48 \mathrm{~cm}$ below ground surface on 1-June) occurred in the "wet" years and WY2016 and WY2017. The recession rates were lower in "dry" years and WY2015 (0.38 $\mathrm{cm}$ /day when water table was $105 \mathrm{~cm}$ below ground surface on 1-June). Thus, recession rates are sensitive to the change in storage produced by aquifer recharge during the freshet.

Recharge of the pumice aquifer was estimated from data for 1-October to 1-June. The greater recharge occurred in WY2011 $(84 \mathrm{~cm})$ and WY2016 $(83 \mathrm{~cm})$ with less in WY2012 $(63 \mathrm{~cm})$, the "wet" years. Less recharge occurred in WY2013 $(41 \mathrm{~cm})$ and WY2014 $(43 \mathrm{~cm})$ the "dry" years. Recharge in WY2015 (56 $\mathrm{cm}$ ) was intermediate between "wet" and "dry" years. Storage was lowest on 30-September in WY2014 and WY2015 when 30 percent and 34 percent, respectively, of the pumice aquifer was saturated. The greatest saturated thicknesses on 1-June were observed in WY2011 and WY2017 when the saturated thickness was 79 percent and 76 percent, respectively.

A second site that illustrates groundwater response in this group was located near FSLR 460 (B on Figure 2). Here, the water table was consistently deeper than $130 \mathrm{~cm}$ on 1-June and below the rooting zone of many plants. The site lies south of a shield volcano that separated the Round Meadow/Sellers Marsh closed-basin catchment to the north from the upper Jack Creek catchment to the south. The elevation difference between the highest point on the shield volcano and the piezometer $1.7 \mathrm{~km}$ away was approximately $14 \mathrm{~m}$. Local relief was controlled by the morphology of basalt lava flows from the shield volcano. The most prominent hydrogeologic feature was the FSLR 460 fen [9] that emerged to the east of this piezometer site by approximately $40 \mathrm{~m}$.

Figure 4 presents the hydrograph for the FSLR 460 piezometer site. In the four water years of record the water table recession rates were between 0.30 $\mathrm{cm} /$ day and $0.37 \mathrm{~cm} /$ day, rates that were similar to the "dry" years at the FSLR510 site when the water table remained below the main rooted zone. Storage in the pumice aquifer was lowest in WY2014 and WY2015 when 24\% of the aquifer thickness was saturated at the end of the water years. The low saturated thickness of the pumice aquifer in WY2014 and WY2015 coincided with local desiccation of peat deposits in the neighboring FSLR460 fen ([9], Figure 13 therein). On 3-June-2017, a high precipitation year with $23.6 \mathrm{~cm}$ SWE on 1 -April, $50 \%$ of the aquifer thickness was saturated.

\subsection{Piezometers Screened in the Partially Eroded Pumice Aquifer Where Confined by Alluvial or Lacustrine Deposits}

The second group of piezometers includes those installed in auger holes used to determine stratigraphy in ephemeral stream valleys and lake beds cut into the pumice deposit. This group also includes three sites where the uneroded pumice deposit was covered by alluvium. After the eruption of Mount Mazama the drainage network began to evolve. Streams followed the pre-eruption landscape 


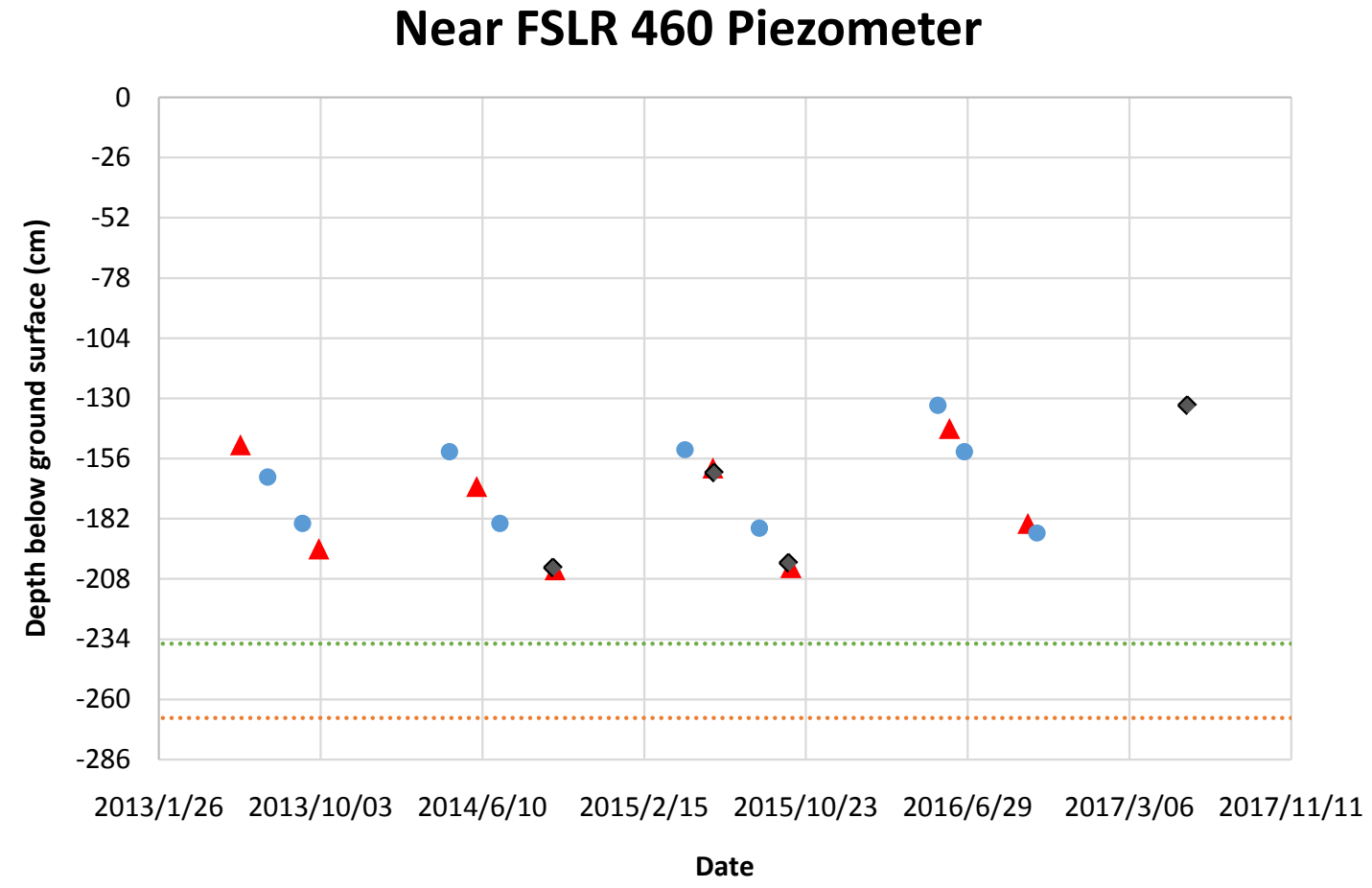

Figure 4. Depth to water table from ground surface for piezometer located near FSLR460 (Zone 10, 0611675E, $4795655 \mathrm{~N})$. Black diamonds are field-measurement depth made between 1-June and 4-June and 26-September and 30-September of each water year. Red triangles are estimated depth to water table on 1-June or 30 -September of each water year. Blue dots are measurements made on specific dates, period of record from 13-July-2013 to 4-June-2017. Auger hole was $286 \mathrm{~cm}$ deep with piezometer open to $236 \mathrm{~cm}$ (green dotted line). Pumice-pre-eruption contact was $268 \mathrm{~cm}$ below ground surface (orange dotted line).

template and eroded into and locally through the pumice deposit. Five to $10 \mathrm{~cm}$ of lag sand comprised of angular to sub-angular crystals (phenocrysts), and sub-rounded lithics overlie the scour surface. Following this early stage of erosion, glassy silt, fine-grained glassy sand, and rounded granules to pebbles of pumice were deposited forming flat bottomed valley floors cut into the pumice deposit. In these settings the aquifer was the remnant of the lower pumice unit and the lag sand. A second feature of the drainage network consisted of shallow lakes that ponded upstream from bedrock-lined constrictions in the pre-eruption landscape. The Round Meadow system illustrates this environment [10] [13]. In these environments the upper pumice unit was absent and the eroded surface cut into the lower pumice was overlain by lag sand. Above the lag sand was rounded pumice that settled through the water column. This, in turn, was overlain by diatom-bearing glassy silt and fine-grained sand that graded upward to organic-bearing silt. Here, the aquifer includes remnants of the lower pumice deposit, the lag sand, and the water-settled, rounded-pumice deposit. In both settings, the fine-grained deposits that overlie the hybrid aquifer (pumice, lag sand, \pm settled pumice) isolate to varying degrees surface water from groundwater in the aquifer [10] [13].

Forty-four single piezometers were used to monitor ground water levels and 
two sites have been selected to illustrate storage in these settings. The first was an alluvial site east-northeast of the Johnson fen and the second was a lacustrine site in Round Meadow (C and D, respectively, Figure 2).

Settings where alluvium overlies the partially eroded pumice aquifer are illustrated by a low-relief valley that extends southward from the Wilshire fen at its north end, passes by the Johnson Meadow fen, to its confluence with Jack Creek (Figure 2). Elevation drops approximately $2.5 \mathrm{~m}$ over a distance of approximately $3.7 \mathrm{~km}$. The contact between alluvium and underlying pumice aquifer of the ephemeral stream valley within this larger pre-eruption valley cuts progressively deeper into the pumice aquifer until the pre-eruption surface was intersected near the Johnson Meadow fen. Bedrock included basaltic palagonitic tephra, fine-grained volcaniclastic sedimentary rocks, and an unwelded pyroclastic flow (well logs in [12]).

Two distinct tributary valleys enter the north-south valley, one from the east and one from the west (Figure 2). Surface flow was observed in this valley system on 1-June only in WY2011 and WY2017. Figure 5 contains a hydrograph from a piezometer located in the tributary valley that enters from the east ( $\mathrm{C}$ in Figure 2). At this site, $74 \mathrm{~cm}$ of alluvium including $8 \mathrm{~cm}$ thick lag sand overlie a remnant of the upper pumice unit $(42 \mathrm{~cm})$ and the entire thickness of the lower pumice unit ( $160 \mathrm{~cm}$, Figure 5). In WY2014 the water table dropped beneath

\section{East Tributary Valley, Easternmost Piezometer}

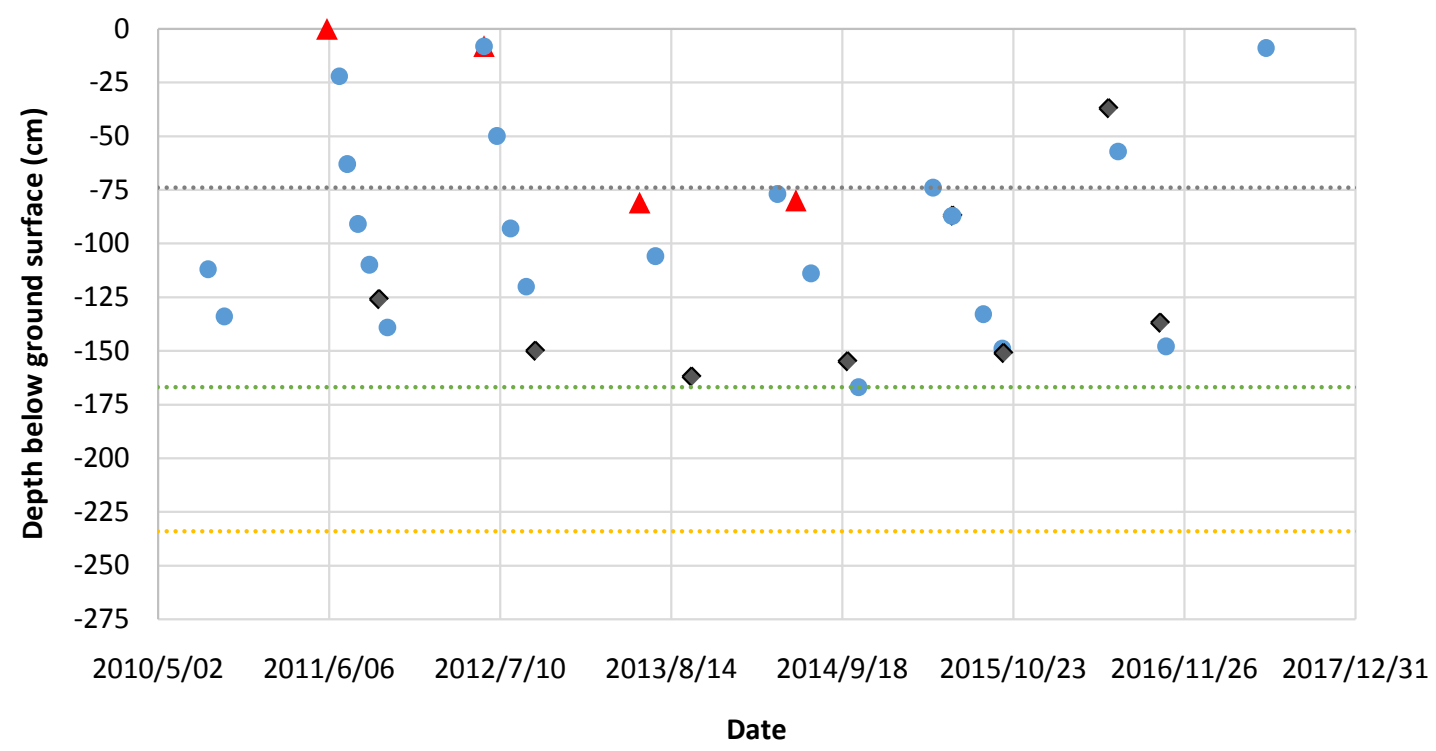

Figure 5. Hydrograph for piezometer located in the eastern tributary valley to the Wilshire-Johnson corridor (C in Figure 2) (Zone 10, 0615339E, 4791803N). Alluvium was $74 \mathrm{~cm}$ thick and overlies partial thickness of the upper pumice and the full thickness of the lower pumice unit. Red triangles are field-measurements depths on 1-June of indicated water years. Black diamonds are calculated depths to water table for 1-June and 30-September. Record extends from 26-August-2010 to 3-June-2017. The gray dotted line is the contact between alluvium and the pumice aquifer. The green dotted line is the depth of the piezometer $(167 \mathrm{~cm})$. The yellow dotted line is the depth of the augur hole. The estimated depth to pumice-pre-eruption contact was 275 $\mathrm{cm}$. 
the maximum depth of the piezometer $(167 \mathrm{~cm})$.

The depth to water table on 1-June follows patterns similar to those observed at sites described in Section 4.1. In "wet" years (WY2011 and WY2012) the water table on 1-June was above or near the surface while in "dry" years (WY2013 and WY2014) the water table on 1-June was greater than $80 \mathrm{~cm}$ below ground surface. Again, WY2015 follows the "dry" pattern, but has an even deeper water table on 1-June than the drought year of WY2014. The pattern for WY2016 and WY2017 were similar to the "wet" years, but the water table did not reach the surface. The frequency of measurements in WY2011 allowed a change in rate of recession to be detected that mirrored the depth of water table relative to the depth of the contact between fine-grained alluvium, lag sand, and pumice deposit. From 1-June to 12-August the rate of decline was $1.3 \mathrm{~cm} /$ day while the water table was in the heavily rooted zone hosted by alluvium. From 12-August to 20 -October the rate of recession was $0.7 \mathrm{~cm} /$ day while the water table was hosted within the pumice aquifer. Recharge in "dry" years was not enough to raise the water table into the alluvium, rather the water table remained within the pumice deposit during those years. The recharge was even less in WY2015. The 1-June position of the water table within the pumice aquifer in these three water years $(-81 \mathrm{~cm}$ in $2013 ;-80 \mathrm{~cm}$ in $2014 ;-87 \mathrm{~cm}$ in 2015$)$ was consistent with lower recession rates during those years $(0.67 \mathrm{~cm} /$ day in $2013 ; 0.57 \mathrm{~cm} /$ day in $2014,0.50$ $\mathrm{cm} /$ day in 2015).

The second site that illustrates this stratigraphic relation is located in Round Meadow (D in Figure 2) where Weatherford and Cummings [10] determined interactions between surface- and ground-water systems. The seasonally flooded meadow was found to host two distinct systems. Diatomaceous silt isolated the hybrid pumice aquifer from the surface water system.

The piezometer selected from this site was installed in the southeastern corner of the meadow where alluvial fan deposits ( $40 \mathrm{~cm}$ thick) overlie lacustrine sediments (48 cm thick) which, in turn, overlie the pumice aquifer $(\sim 190 \mathrm{~cm}$ thick; Figure 6). The head of the alluvial fan was where a basalt bedrock-lined ephemeral stream channel entered the meadow. Flow was observed in this channel on 7-March-2015, 13-May-2016, and 3-June-2017. However, the average discharge for these three dates was $\sim 4.8 \times 10^{-3} \mathrm{~m}^{3} / \mathrm{s}$ [10] (unpublished data). Surface water sank into the fan shortly after the channel crossed from bedrock onto the fan.

Although the hydrograph in Figure 6 for this site shares patterns similar to the alluvial site described above, there are several differences. These differences appear to reflect the influence of the bedrock-line ephemeral stream valley that enters the meadow near this piezometer. These differences include the following. 1) The water table in each water year was hosted in the lacustrine/alluvial sediments that overlie the hybrid pumice aquifer on 1-June. On dates when the depth to water table was measured before 1-June, the water table was near the ground surface. 2) Recession rates ranged from $0.71 \mathrm{~cm} /$ day in WY2011 to 1.23 
SE Round Meadow Piezometer

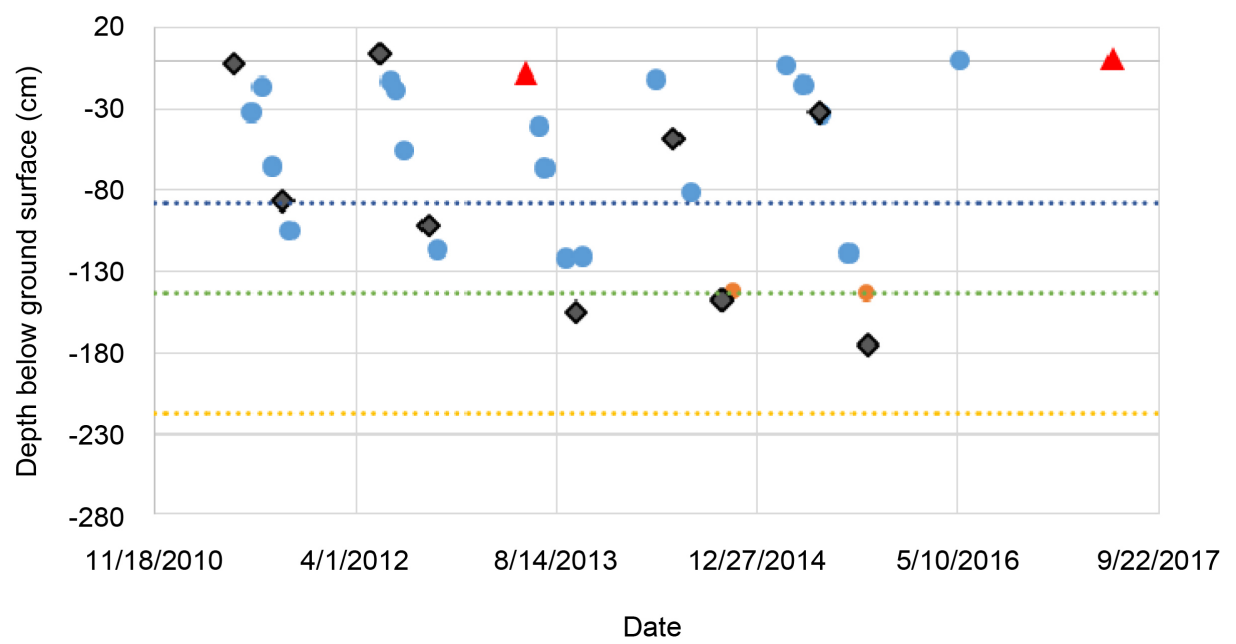

Figure 6. Piezometer located in southeast portion of Round Meadow (D in Figure 2) (Zone 10, 0612236E, 4798205N). Red triangles are field-measured depths between 1-June and 3-June.Black diamonds are estimated depths to water table on 1-June and 30-September. The water table fell below the piezometer in WY2013, WY2014, and WY2015 (orange dots are depths measured when piezometer was dry). Record from 15-July-2011 to 3-June-2017. Dotted blue line is contact between alluvium and lacustrine sediment and the pumice deposit $(88 \mathrm{~cm})$. The green dotted line is the depth of the piezometer $(144 \mathrm{~cm})$. The yellow dotted line is the depth of the auger hole $(218$ $\mathrm{cm})$. Contact between pumice and pre-eruption deposits estimated at $280 \mathrm{~cm}$.

$\mathrm{cm} /$ day in WY2013. This is distinct from most alluvial/lacustrine sites where the recession rate in WY2011, a "wet" year, is greater than those in "dry" years such as WY2013. 3) In WY2015, the early season recession rate was considerably lower than near the end of the water year. Access to the site was possible on 7-March-2015 in the morning while roads were still frozen. Between this date and 3-June, the recession rate was $0.34 \mathrm{~cm} /$ day with the water table within $3 \mathrm{~cm}$ of ground surface on 7-March when the ephemeral stream was still flowing. The recession rate was greater from 3-June to the end of the water year with an estimated recession rate of $1.19 \mathrm{~cm} /$ day. 4) The depth to water table at this site (Figure 6) shows the greatest response to precipitation of the piezometer network. The depth to water table was measured on 4-September in WY2012 (-122 $\mathrm{cm})$ and estimated for 30 -September $(-145 \mathrm{~cm}$, measured dry at $-144 \mathrm{~cm})$. An early season storm moved through the area on 15/16-October dropping $2.8 \mathrm{~cm}$ of rainfall at the Chemult Alternate SNOTEL Site. Following this event, the water table was measured at $-121 \mathrm{~cm}$ below ground surface on 20-October (Figure 6). Few piezometers responded to this storm event.

\subsection{Relations between Depth to Water Table on 1-June and Recession Rates}

A relation between recession rate of the water table and subsurface storage on 1-June is suggested by data from all piezometers measured in this study. These findings are consistent with findings reported by Garcia and Tague [6] for three 
catchments in the western United States. Data for piezometers located where the pumice aquifer was exposed at the surface (Section 4.1) are presented in Figure 7 and similar data for those located where alluvium or lacustrine sediments overlie the partially eroded pumice aquifer (Section 4.2) are presented in Figure 8. Several observations arise from these plots. 1) The water table at sites plotted in Figure 7 remained below the ground surface at all sites in all years while

\section{Depth to water table on June 1 versus recession rate}

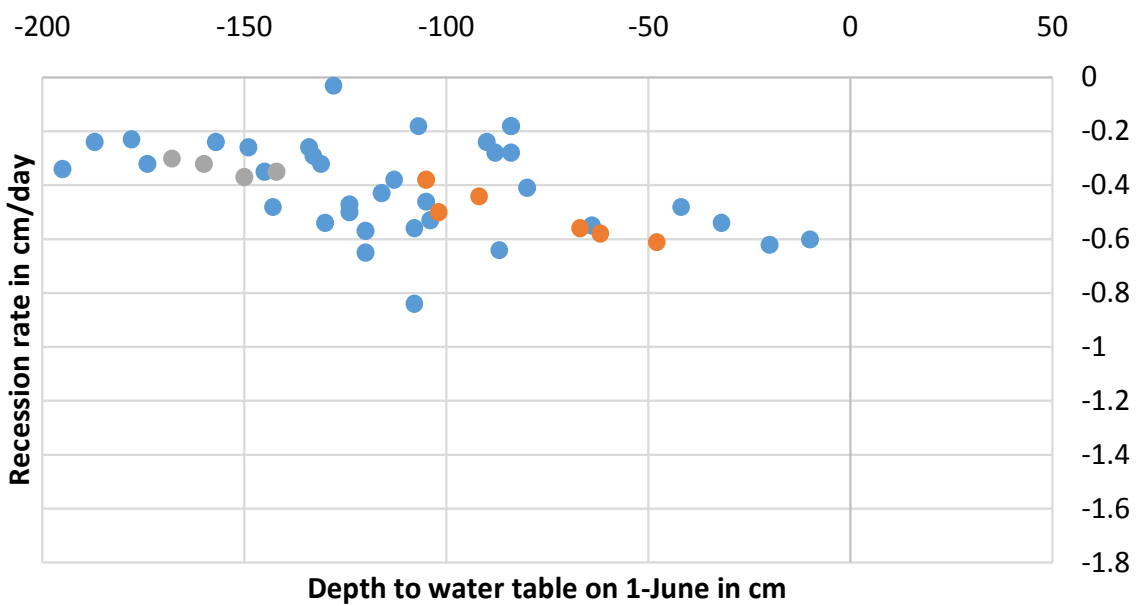

Figure 7. Depth to water table on 1-June versus recession rate of the water table for piezometers located where the pumice aquifer is exposed at the surface (Section 4.1). Data for the FSLR510 piezometer (Figure 3) are shown in red. Data for the FSLR460 piezometer (Figure 4) are shown in gray.

\section{Depth to water table on June 1 versus recession rate}

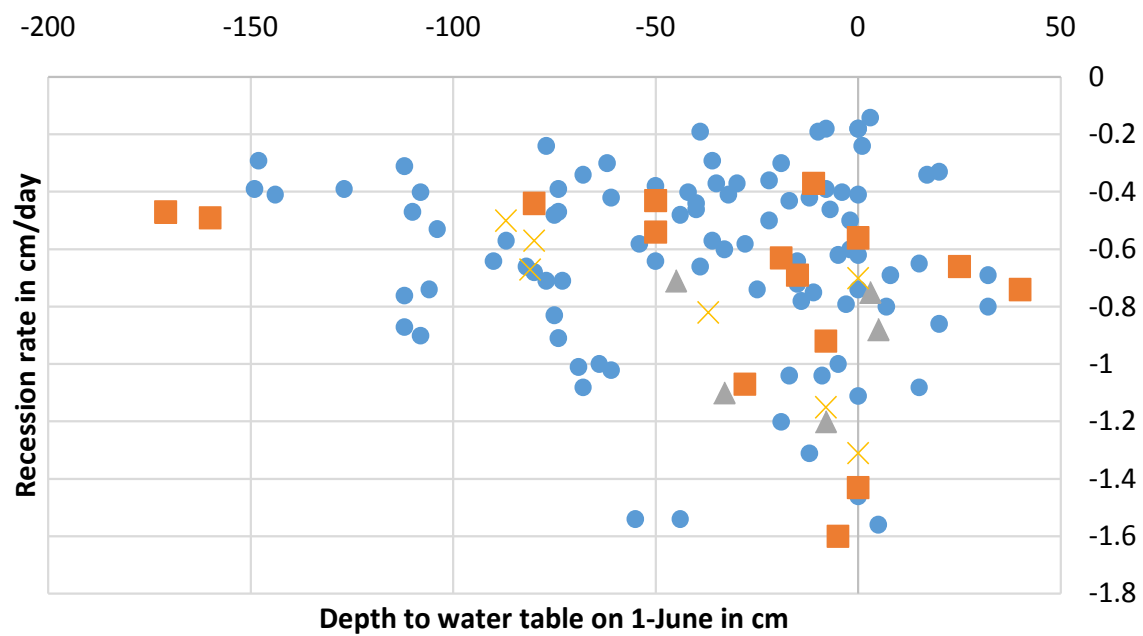

Figure 8. Depth to water table on 1-June versus recession rate for sites where alluvial or lacustrine deposits overlie partially eroded pumice aquifer (Section 4.2). Included (red squares) are sites where the aquifer was only slightly eroded, but was overlain by alluvium. Orange x symbols are for the piezometer in the eastern tributary valley (Figure 5). Gray triangles are data for the piezometer located in southeast Round Meadow (Figure 6). 
surface water was present at sites plotted in Figure 8. 2) Vegetation at sites plotted in Figure 7 was dominated by Lodgepole pine with sparse understory dominated by bitter brush while understory vegetation was abundant and/or treeless meadows with abundant vegetation were characteristic of sites plotted in Figure 8. These settings are important sources of summer forage. 3) Overall, recession rates for sites plotted in Figure $7(<\sim 0.7 \mathrm{~cm} /$ day) are lower than for sites plotted in Figure 8 (as great as $\sim 1.6 \mathrm{~cm} /$ day). In both settings, lower recession rates occur where the 1-June depth to water table is greater than about $1 \mathrm{~m} .4$ ) Depths to water table on 1-June less than $1.0 \mathrm{~m}$ are more common at sites plotted in Figure 8 than in Figure 7. This relation reflects the lower permeability of alluvium and lacustrine sediments versus pumice and abundant vegetation and well-developed rooted zones where sediments are present.

These relations reflected the difference in function of the pumice deposit and reworked deposit. The function of the pumice deposit was primarily storage of groundwater. The function of reworked deposits was conveyance of surface water from the system.

\subsection{Fens where the Pumice Aquifer Is Confined by Peat Deposits}

The internal stratigraphy of five fens was described by Cummings et al. [9] and Weatherford and Cummings [10] and the biodiversity and environmental flows and levels were presented by Aldous et al. [11] and Aldous and Bach [15]. The morphology of fens was characterized by a sloping surface underlain by peat which locally graded laterally to organic-rich fine-grained sandy silt with medium- to coarse-grained rounded pumice sand. These materials form the upper confining layer to the pumice aquifer. Peat was thickest $(\sim 1.2 \mathrm{~m})$ where the potentiometric surface in the underlying pumice aquifer was above ground surface during much of the growing season. However, in "dry" years and especially in WY2014 and WY2015 the potentiometric surface in some fens was below the ground surface throughout the growing season and locally retreated below the confining layer [10]. Under these conditions, the bryophyte-rich plant community that dominated these fens turned brown and the normal springy nature of the ground surface decreased.

An erosion surface marked the contact between the peat or organic-rich sandy silt confining layer and the underlying pumice aquifer. This contact cut downward through the pumice deposit and locally to the pre-eruption surface. In some fens, piping features rose from the pumice aquifer through the peat confining layer and discharged groundwater to low-volume streams which flowed across the peat surface. Focused discharge from these streams and diffuse discharge through the fen surface accumulated in small pools or streams at the toe of the fen. This discharge contributed to perennial stream flow in the upper reaches of Jack Creek. However, locally, the discharge ponded against low-relief berms that marked the surface boundary between the fen and neighboring alluvium-floored, ephemeral stream valleys [10]. These berms were spatially asso- 
ciated with iron cementation in the underlying remnants of the pumice aquifer.

Nested piezometers were installed in three fens (Wilshire, Johnson Meadow, and Dry Meadow) by The Nature Conservancy in collaboration with the Fremont-Winema National Forest [11] to estimate environmental flows and levels. Later, single piezometers were installed in areas neighboring these fens to provide context to the fen environment. In addition, single piezometers and piping features were monitored in four additional fens. The hydrographs varied considerably within an individual fen, among fens, and between the fens and adjacent areas. These differences are described in Aldous et al. [11], Cummings et al. [9] and Weatherford and Cummings [10]. Groundwater that diffusely discharged through the fen surface was from the pumice aquifer. However, the source of this groundwater included groundwater flowing through the pumice aquifer from the melting of annual snowpack and, to varying degrees, groundwater flowing along bedrock contacts and along faults [9] [10] [11]. These additional sources of groundwater modify the groundwater recession pattern. In fens, the recession rate for the pumice aquifer is lower until late July to early August and increases from that time through the end of the water year.

Figure 9 presents data for two piezometers from the Wilshire fen (Figure 2). Piezometer W5-1.4 was located near the upper level while W6-1.4 was near the toe of the sloping fen surface. The difference in surface elevation is approximately $2 \mathrm{~m}$. The thickness of peat at the W5 and W6 sites was $52 \mathrm{~cm}$ and 119 $\mathrm{cm}$, respectively [16]. Both piezometers were screened in the pumice aquifer. The water level in the W6-1.4 piezometer was consistently above the ground surface throughout all water years while, higher on the slope, the W5-1.4 was above the ground surface into August, but dropped below the ground surface by

Wilshire fen W6-1.4 and W5-1.4

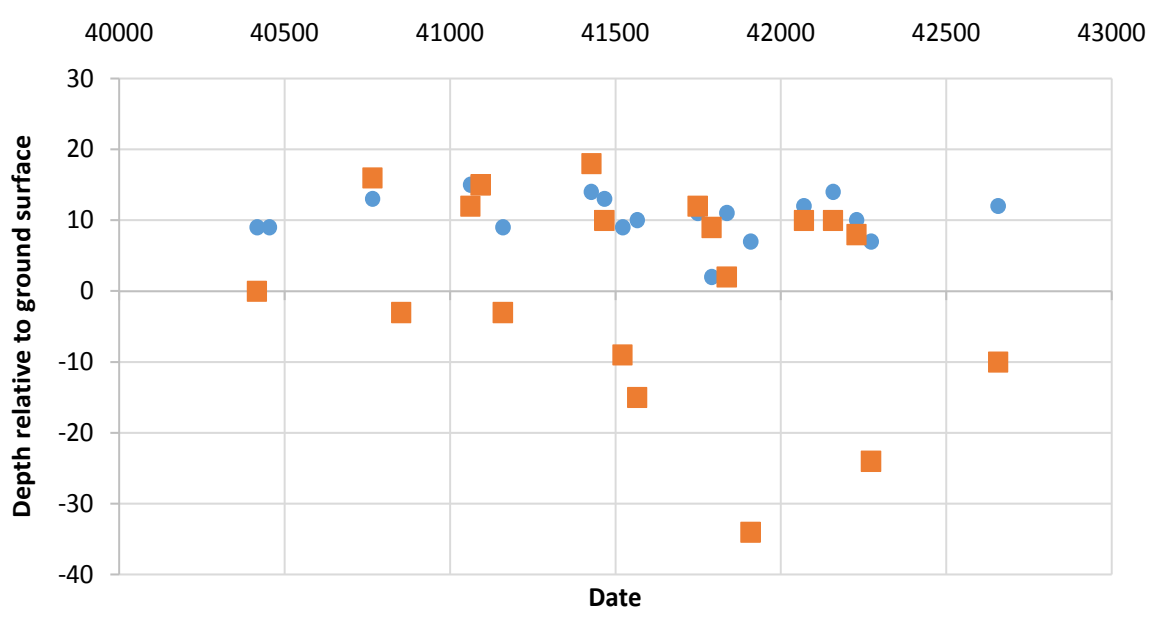

Figure 9. Hydrographs for two piezometers from the Wilshire fen starting WY2010 and ending in WY2017. Piezometer W6-1.4 (blue dots) was located at the toe of the fen (Zone $10,0613735 \mathrm{E}, 4795135 \mathrm{~N}$ ) while W5-1.4 (red squares) was located near the upper edge of the fen (Zone 10, 0613738E, 4795148N). The elevation difference between these two piezometers is approximately $2 \mathrm{~m}$. 
the end of the water year with the greatest recession noted in WY2014. The late season recession of the water table in WY2015 was similar to the drought year of WY2014.

\subsection{Monitoring Wells}

Ten wells were drilled by the U.S. Forest Service to monitor ground water levels [12]. Piezometers were installed in three closely spaced wells at each of three fens: Johnson Meadow fen, Wilshire fen, and Dry Meadow fen (Figure 2). An additional single well was drilled and piezometer installed in a broad low relief forested area where the pumice aquifer was known to contain water throughout the growing season (Section 5 monitoring well in Figure 2). At the fen sites, shallow wells were between 3.8 and $7.6 \mathrm{~m}$ deep, intermediate wells were between 15.2 and $18.3 \mathrm{~m}$ deep, and the deep wells were between 27.3 and $31.7 \mathrm{~m}$ deep. Table 2 provides information for each well including depth to water table on 10-October-2010, 6 to 10 days after installation. Between the surface and refusal against resistant bedrock, a $45.7 \mathrm{~cm}$ split-spoon sampler was used to recover $\sim 45$ $\mathrm{cm}$ long samples for every $\sim 76 \mathrm{~cm}$ of hole drilled. From refusal to final depth 6.4 $\mathrm{cm}$ diameter core was recovered. Piezometers were installed in each well in sections interpreted to be potential aquifers [12].

At the three fens, the wells were upslope from the "wetland on dry ground amongst Lodgepole pine trees" [12]. The distance between the wells and the nearest nested piezometers in the fens ranged from $10 \mathrm{~m}$ at Dry Meadow fen to $45 \mathrm{~m}$ at Johnson Meadow fen. The contact between the pumice unit and pre-eruption surface was 2.4 to $3.1 \mathrm{~m}$ below ground surface. The deepest wells were completed in vesicular basalt flows or breccia and were found to be dry 6 to 10 days after completion. Between $14 \mathrm{~cm}$ and $90 \mathrm{~cm}$ of water was detected in the intermediate depth wells screened in basaltic breccia (Dry Meadow), vesicular

Table 2. Characteristics of ten monitoring wells [12].

\begin{tabular}{ccccc}
\hline & $\begin{array}{c}\text { Augered } \\
\text { interval }(\mathrm{m})\end{array}$ & $\begin{array}{c}\text { Cored } \\
\text { interval }(\mathrm{m})\end{array}$ & $\begin{array}{c}\text { Piezometer } \\
\text { screened } \\
\text { interval }(\mathrm{m})\end{array}$ & $\begin{array}{c}\text { Water table }^{*} \text { on } \\
\text { 10-Oct-2010 }(\mathrm{m})\end{array}$ \\
\hline Dry Meadow 1 & $0-3.81$ & & $2.29-3.81$ & 1.13 \\
Dry Meadow 2 & $0-3.05$ & $3.05-15.24$ & $10.67-15.24$ & 14.90 \\
Dry Meadow 3 & $0-3.05$ & $3.05-27.28$ & $22.23-27.28$ & Dry \\
Johnson Meadow 1 & $0-6.70$ & & $1.83-3.35$ & 1.31 \\
Johnson Meadow 2 & $0-7.61$ & $7.61-13.72$ & $10.67-13.70$ & 13.56 \\
Johnson Meadow 3 & $0-7.61$ & $7.61-29.20$ & $24.32-28.90$ & Dry \\
Wilshire 1 & $0-4.57$ & & $1.83-2.03$ & 1.42 \\
Wilshire 2 & $0-9.14$ & $9.14-18.29$ & $13.40-18.29$ & 17.39 \\
Wilshire 3 & $0-9.14$ & $9.14-31.85$ & $27.25-31.70$ & Dry \\
Section5 & $0-6.10$ & $6.10-15.18$ & $1.52-6.10$ & 1.26 \\
\hline
\end{tabular}

${ }^{*}$ Depth to water table measured from the top of the piezometer [12]. 
basalt (Johnson Meadow) or unwelded pyroclastic flow and basaltic hydrovolcanic tuff (Wilshire). In all cases, the productive aquifer was the pumice aquifer underlain by lower permeability regolith or bedrock units.

Depth to water table from the top of the piezometers has been monitored since installation. Figure 10 contains the hydrograph for Wilshire 1 at the Wilshire fen (Table 2). The well was spudded in the soil horizon developed from pumice and therefore was similar to the hand-augered holes described in Section 4.1. Wilshire 1 was approximately $40 \mathrm{~m}$ from piezometer W5-1.4 described in Section 4.4 and surface elevation was approximately $1.5 \mathrm{~m}$ higher. The recession rate in Wilshire 1 from 1-June to 30-September ranged from $0.62 \mathrm{~cm} /$ day to 0.70 $\mathrm{cm} /$ day with similar rates for both "wet" and "dry" years. In comparison, recession rates of similar value were not observed in the W5-1.4 piezometer until after the beginning of August and only in WY2014 and WY2015. On 3-June-2015 the water table in Wilshire 1 was the deepest recorded for early June during six years of record. In contrast, the potentiometric surface at W5-1.4 on that date was above ground surface, similar to all other years. Fluctuation in the water table was considerably greater in the monitoring well in all years $(75 \mathrm{~cm}$ to $85 \mathrm{~cm})$ than the maximum in either piezometer in the fen (W5-1.4 = $36 \mathrm{~cm}$ in WY2014; $\mathrm{W} 6-1.4=7 \mathrm{~cm}$ in WY2015).

In general, for monitoring wells, the greatest recession occurred in WY2014 and WY2015 when water tables on 30-September were 25 to $37 \mathrm{~cm}$ lower, respectively, than the first measured date (10-Ocotober-2010) at the three fens. The recession was less in the single isolated well where the water table declines were only 11 and $14 \mathrm{~cm}$, respectively, compared to 10-October-2010.

\subsection{Surface Water}

The two catchments had relatively minor surface water resources. The largest

Wilshire 1 monitoring well

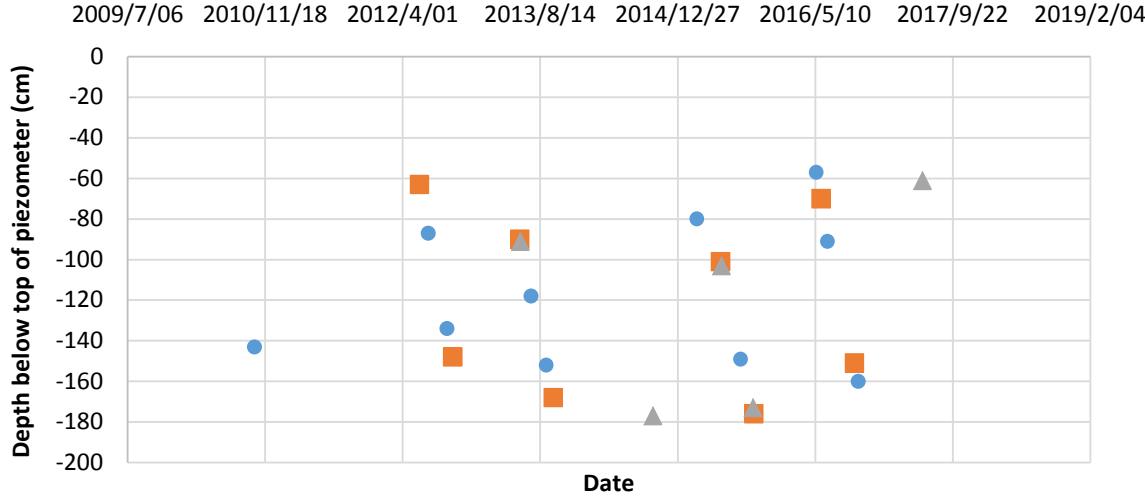

Figure 10. Hydrograph for Wilshire 1 monitoring well at the Wilshire fen (Zone 10, 0613717E, 4795181N). Initial date of measurement was 10-October-2010, 7 days after the well was drilled and piezometer installed [12]. Gray triangles are depths to water table from the top of the piezometer measured 1-June or 30-September. Red squares are calculated depths to water table for 1-June or 30-September assuming recession was linear. 
area of surface water was Sellers Marsh in the Round Meadow/Sellers Marsh closed basin, but this site was not available for study. Round Meadow in the same closed basin had an area of approximately $0.42 \mathrm{~km}^{2}$ when it was flooded. By late summer in "dry" years surface water was confined to the largest canals that were constructed in the 1960s to drain the wetland. Surface water discharge to Sellers Creek occurred when the depth of water in the meadow exceeded the elevation of the bedrock knickpoint at the head of Sellers Creek. The perennial reach of Sellers Creek extended for approximately $6.5 \mathrm{~km}$ from the knickpoint and was maintained by discharge from the meadow and from springs discharging from fractured welded tuff that formed the knickpoint [10]. Peak discharge occurred during the freshet which by the 1-June measurement dates was in the past. Discharge during winter months is poorly known. However, on 21-January-2015 estimated discharge was $1.7 \times 10^{-2} \mathrm{~m}^{3} / \mathrm{s}$. At this time of year discharge was expected to be about $7 \times 10^{-3} \mathrm{~m}^{3} / \mathrm{s}$. Base flow maintained primarily by spring discharge and measured at FSCR 9405 was between $1.2 \times 10^{-3} \mathrm{~m}^{3} \cdot \mathrm{s}^{-1}$ and $2.1 \times 10^{-3} \mathrm{~m}^{3} \cdot \mathrm{s}^{-1}$.

Perennial flow was also present in approximately $11 \mathrm{~km}$ of Jack Creek. Base flow in the perennial reach is maintained by discharge from springs issuing from contacts between basalt flows and between lava flows and lower permeability bedrock units. In this environment, springs are noted for discrete points of discharge, but in many cases the groundwater discharge was into the pumice aquifer and released through fens. Base flow in Jack Creek was measured at FSCR 9418 (Figure 2) in the midsection of the reach that experienced perennial flow. Here, base flow was estimated between $5 \times 10^{-2} \mathrm{~m}^{3} \cdot \mathrm{s}^{-1}$ and $7 \times 10^{-2} \mathrm{~m}^{3} \cdot \mathrm{s}^{-1}$. Perennial flow ceased near FSCR 8821 (elevation $\sim 1592 \mathrm{~m}$ ) (Figure 2) where discharge through the culvert stopped by late July in most years (Table 3 ) and did not resume until the freshet. In the drought of WY2014 the culvert was already dry on 7-July-2014 and remained so at least through 10-December-2014 in WY2015. However, Figure 11 shows this culvert on 23-December-2014 after rain-dominated storms hit the area between 17- and 22-December. Discharge on 23-December was estimated at 3.0 to $3.5 \mathrm{~m}^{3} / \mathrm{s}$. On 21-January-2015, after another rain event (15-19-January), discharge was estimated at 0.8 to $0.9 \mathrm{~m}^{3} / \mathrm{s}$. However, on 3-June-2015 discharge through the flat-bottomed culvert was too low to measure with a Swoffer model 2100 current velocity meter. An improvised gaging location at a channel constriction downstream from the culvert yielded discharge of $0.18 \mathrm{~m}^{3} \cdot \mathrm{s}^{-1}$. In comparison, discharge on 2-June-2012 and 4-June-2017 through the culvert was $\sim 4 \mathrm{~m}^{3} \cdot \mathrm{s}^{-1}$ and $3.15 \mathrm{~m}^{3} \cdot \mathrm{s}^{-1}$, respectively.

Perennial flow was also present in channel lengths of $10 \mathrm{~m}$ to $100 \mathrm{~m}$ near fens and low volume springs. Discharge from springs in the Round Meadow system [10] remained similar throughout the drought of WY2014 $\left(9 \times 10^{-4}\right.$ to $1.5 \times 10^{-3}$ $\left.\mathrm{m}^{3} \cdot \mathrm{s}^{-1}\right)$, but were approximately halved by the end of WY2015. Discharge returned to previously observed levels in WY2016.

The ephemeral drainage network conveyed water during the freshet in "wet" 
Table 3. Discharge from upper Jack Creek basin measured at FSCR 8821 (Figure 2). The catchment upstream from this location is estimated at $125 \mathrm{~km}^{2}$.

\begin{tabular}{|c|c|}
\hline \multicolumn{2}{|c|}{ Discharge on Jack Creek at FSCR 8821} \\
\hline Date & Discharge in $\mathrm{m}^{3} \cdot \mathrm{s}^{-1}$ \\
\hline 2-June-2012 & $\sim 4$ \\
\hline 29-June-2012 & 0.52 \\
\hline 6-July-2012 & 0.13 \\
\hline 2-August-2012 & Dry \\
\hline 8-September-2012 & Dry \\
\hline 20-October-2012 & Dry \\
\hline 27-April-2013 & 0.87 \\
\hline 1-June-2013 & 0.25 \\
\hline 7-July-2013 & Dry \\
\hline 1-June-2014 & 0.12 \\
\hline 7-July-2014 & Dry \\
\hline 26-September-2014 & Dry \\
\hline 10-December- $2015^{2}$ & Dry \\
\hline 27-December-2015 3 & $3.0-3.5$ \\
\hline 21-January-2015 & $0.8-0.9$ \\
\hline 18-April-2015 & 0.68 \\
\hline 3-June-2015 & 0.18 \\
\hline 13-August-2015 & Dry \\
\hline 27-September-2015 & Dry \\
\hline 24-June-2016 & 0.29 \\
\hline 14-October-2016 & Dry \\
\hline 4-June-2017 & 3.15 \\
\hline
\end{tabular}

${ }^{1}$ Flow meter not functioning properly, discharge estimated from depth of water column, estimated velocity, and comparison to discharge measured under similar conditions. ${ }^{2}$ Forest Service personnel fide T. Simpson, 31-December-2014. ${ }^{3}$ Discharge estimated from water depth of $34.7 \mathrm{~cm}$ in culvert and velocity estimated from similar conditions on other dates. Depth measured by T. Simpson, 27-December-2014. ${ }^{4}$ Discharge estimated from water depth of $22.5 \mathrm{~cm}$ in culvert and velocity estimated from similar conditions on other dates. Depth measured by T. Simpson, 21-January-2015.

years (Figure 12), but in "dry" years, evidence of flow or standing water in discontinuous channels (dried cyanobacteria mats) during the freshet were absent. Ephemeral stream valleys tended to be flat bottomed and to be underlain by alluvium which overlies remnants of the pumice aquifer. The alluvium forms a variably effective upper confining layer for the pumice aquifer. In WY2011 and WY2017 artesian flow was observed locally on 1-June from piezometers that passed through the alluvium and were screened in the pumice aquifer (e.g. Figure 12). However, in most years, surface water in the ephemeral stream network was absent. 


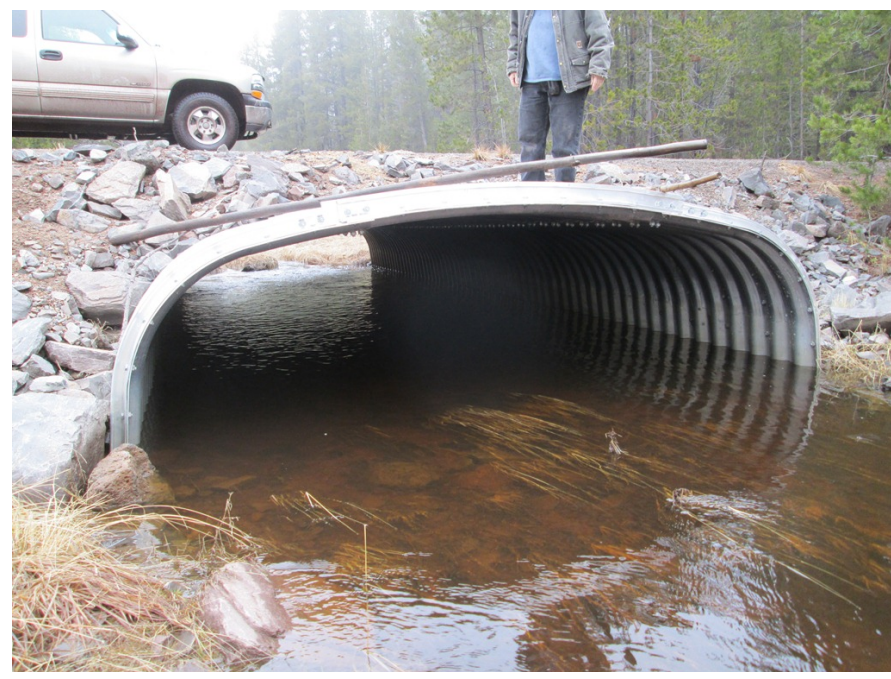

Figure 11. Discharge through the culvert on Jack Creek at FSCR 8821 (Figure 2), the southern limit of the upper Jack Creek basin. Photo was taken on 23-December-2014 and provided by T. Simpson. At that time of year the culvert was expected to be dry. Discharge was estimated between 3.0 and $3.5 \mathrm{~m}^{3} \cdot \mathrm{s}^{-1}$.

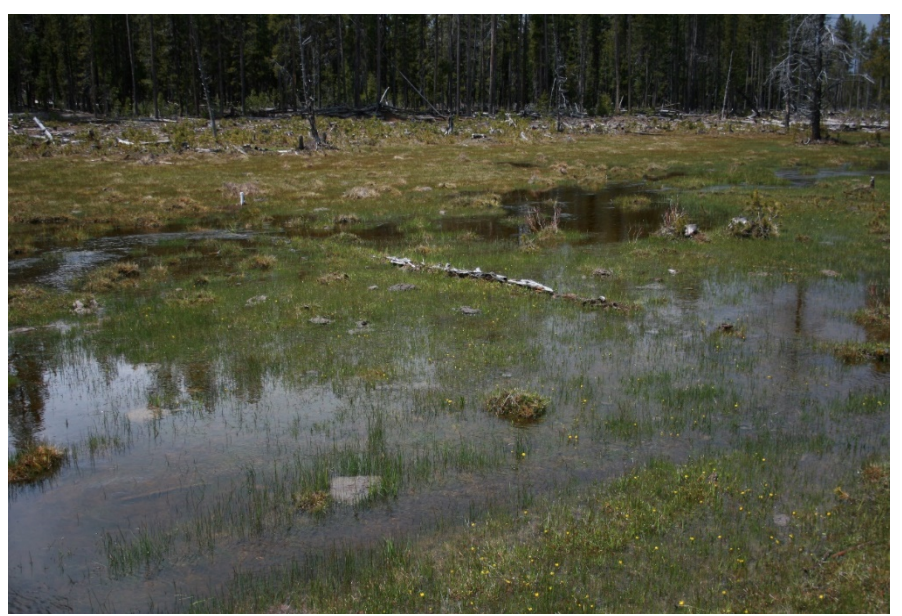

Figure 12. Flat-bottomed, alluvium-floored, ephemeral stream valley on 1-June-2011. During this "wet" year, surface water was present through the summer and at ground surface on 20-October-2011. The white pipe is a piezometer that passed through the alluvium and was slotted in $100 \mathrm{~cm}$ of the lower pumice deposit. In WY2011, artesian flow from the piezometer was noted during the summer. There was no surface water on 1-June-2014 and 3-June-2015. The western edge of the valley is near the forest boundary in this picture where the bank rises approximately $50 \mathrm{~cm}$ above the valley floor.

\section{Precipitation Patterns}

Change in storage in the pumice aquifer follows annual precipitation patterns. During the water years considered in this study, maximum storage was attained in April/May followed by steady decline to minimum storage in Septem- 
ber/October. The decline in storage coincided with the six months, April through September, when evapotranspiration rates were highest [13] and between 8 percent (WY2016) and 31 percent (WY2010) of the annual precipitation was received. With the exception of WY2015, winter precipitation was received as snow with steady increase in SWE until melting began in late February. Figure 13 presents the difference in snow cover in the upper Jack Creek basin and Round Meadow/Seller Marsh catchments on 18-April-2011 (Figure 13(a)), a "wet" year (Table 1), and 7-January-2015 (Figure 13(b)), the water year when winter precipitation fell primarily as rain.

Figure 14 compares precipitation data from the Chemult Alternate SNOTEL station for WY2015 to the 30 year (WY1981-WY2010) average cumulative precipitation curve and the median snow water equivalent curve. Although the cumulative precipitation curve from October to March is above the 30-year average, the SWE curve indicates the precipitation was received primarily as rain.

In addition to precipitation data for the Chemult Alternate SNOTEL station during the study years, records of ground temperature were available within the study area at $50 \mathrm{~cm}$ below ground surface within the pumice deposit (Section 4.1 setting). An Onset temperature/relatively humidity logger recorded conditions at least every 60 minutes. Table 4 reports the date for each water year when warming started at $50 \mathrm{~cm}$ below ground surface and the ground temperature on that date and on 1-June. The instrumented site was located in a flat area in

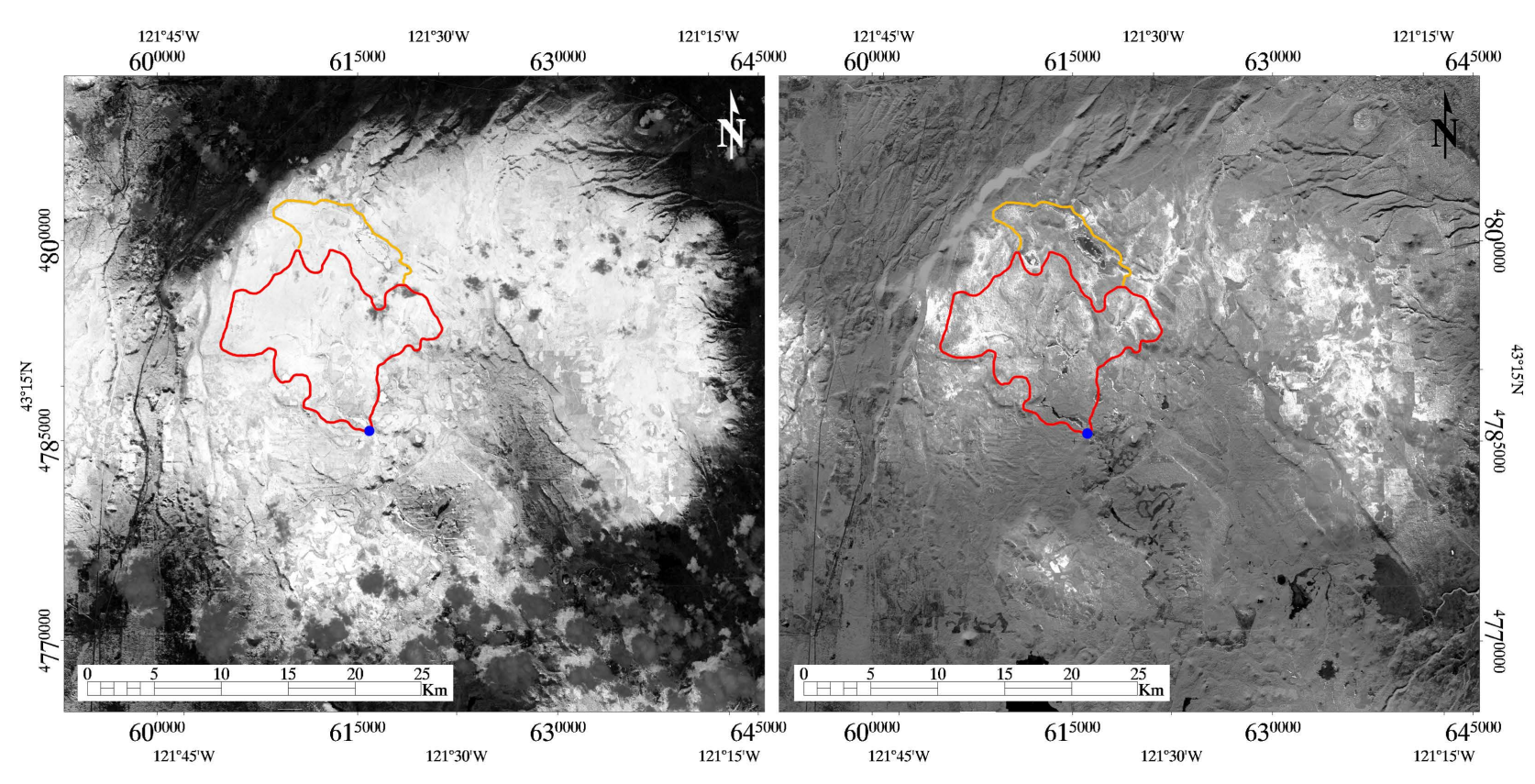

(a)

(b)

Figure 13. (a)-(b): Snow cover in the upper Jack Creek catchment (red) and the Round Meadow/Sellers Marsh closed-basin catchment (yellow) on 18-April-2011 7-January-2015 (b) On 18-April-2011 (a) SWE at the Chemult Alternate SNOTEL Site was 17.3 $\mathrm{cm}$ and cumulative precipitation was $70.1 \mathrm{~cm}$. On7-January-2015 (b) SWE was $2.5 \mathrm{~cm}$ and cumulative precipitation was $32.5 \mathrm{~cm}$, $48 \%$ of the annual precipitation. The blue dot is located where Jack Creek passes beneath FSCR 8821 and marks the outlet for the upper Jack Creek catchment. 
Station (395) WATERYEAR (Daily) NRCS National Water and Climate Center - Provisional Data - subject to revision Tue Sep 29 12:18:33 PDT 2015

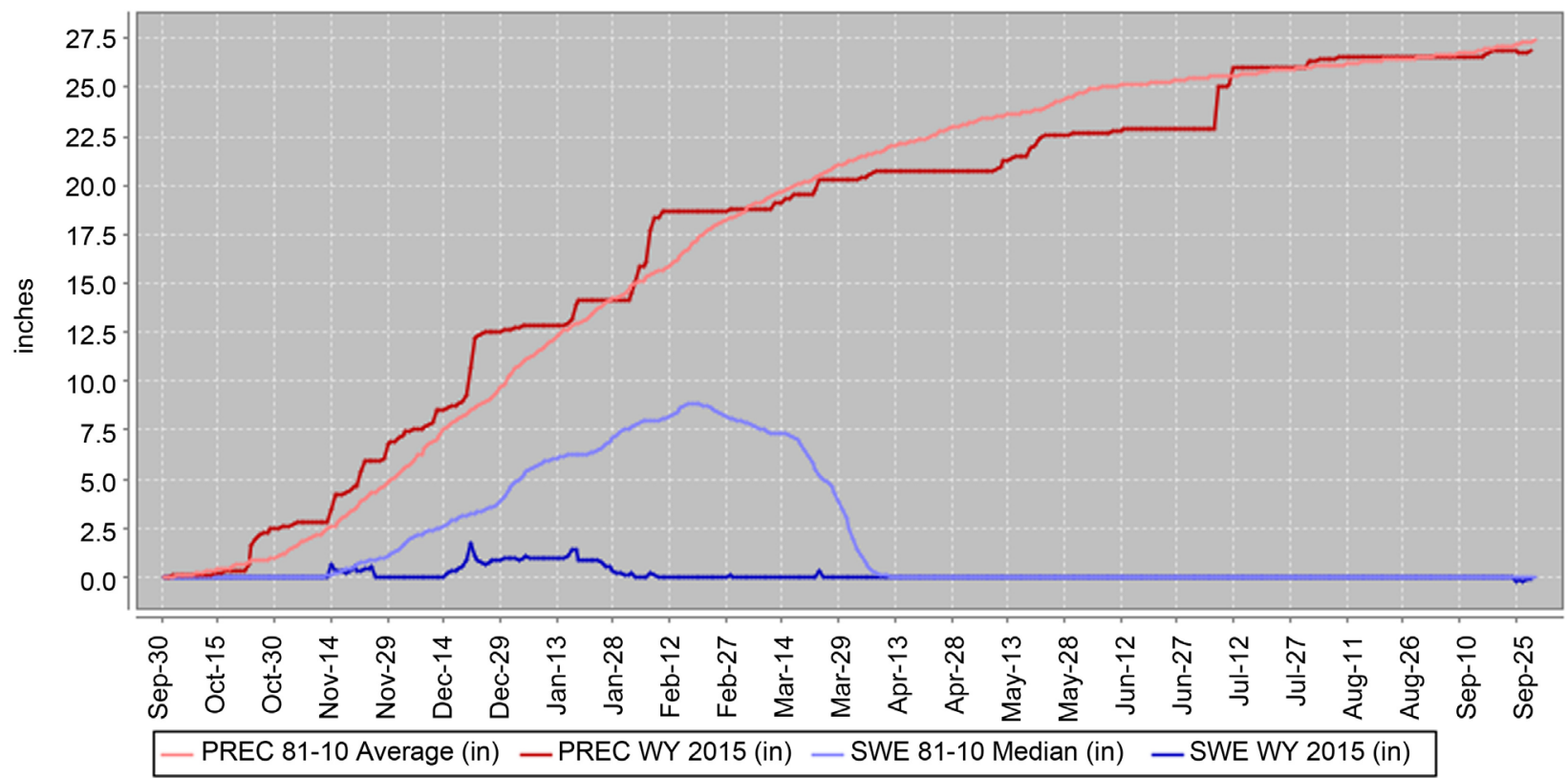

Figure 14. Cumulative precipitation (inches) for WY2015 compared to the average cumulative precipitation between WY1981 the year the station was installed and WY2010. Snow water equivalent (inches) for WY2015 is compared to the median (inches) snow water equivalent since 1981 (http://www.wcc.nrcs.usda.gov/nwcc/site? sitenum=395).

Table 4. Dates when temperatures began to rise at $50 \mathrm{~cm}$ below ground surface using Hobo U23 Pro v2 temperature/relative humidity data loggers. The ground temperature at $50 \mathrm{~cm}$ at the start of warming and on 1-June are included in the third and fourth columns.

\begin{tabular}{cccc}
\hline Water year & Date when warming started at $\mathbf{5 0} \mathbf{c m}$ & Temperature in ${ }^{\circ} \mathrm{C}$ & 1-June Temperature in ${ }^{\circ} \mathrm{C}$ \\
\hline WY2011 & 8-May & 0.66 & 3.8 \\
WY2012 & 28-April & -0.004 & 4.4 \\
WY2013 & 1-April & -0.26 & 6.4 \\
WY2014 & 29-March & -0.09 & 6.7 \\
WY2015 & 15-March & 0.55 & 8.3 \\
WY2016 & 9-April & 0.27 & 6.8 \\
WY2017 & 22-April & 0.47 & 7.7 \\
\hline
\end{tabular}

Lodgepole pine forest. Short-lived (often less than 12 hours) negative deflections in the curves were produced during rain events when water that was colder than the ground migrated downward along the PVC pipe and chilled the cavity where the sensor was located. These deflections occur during approximately the first 75 days of each water year, but are particularly common in WY2015 (Figure 15). During that year, prominent deflections occurred until 8-December-2014. It is assumed by that date the ground around the PVC pipe had frozen and cold rain water no longer had an easy route to travel along. However, compared to other years, temperature fluctuations are common throughout the winter months. The spring of WY2015 was characterized by the earliest onset of warming at $50 \mathrm{~cm}$ 
October, November, December WY2015

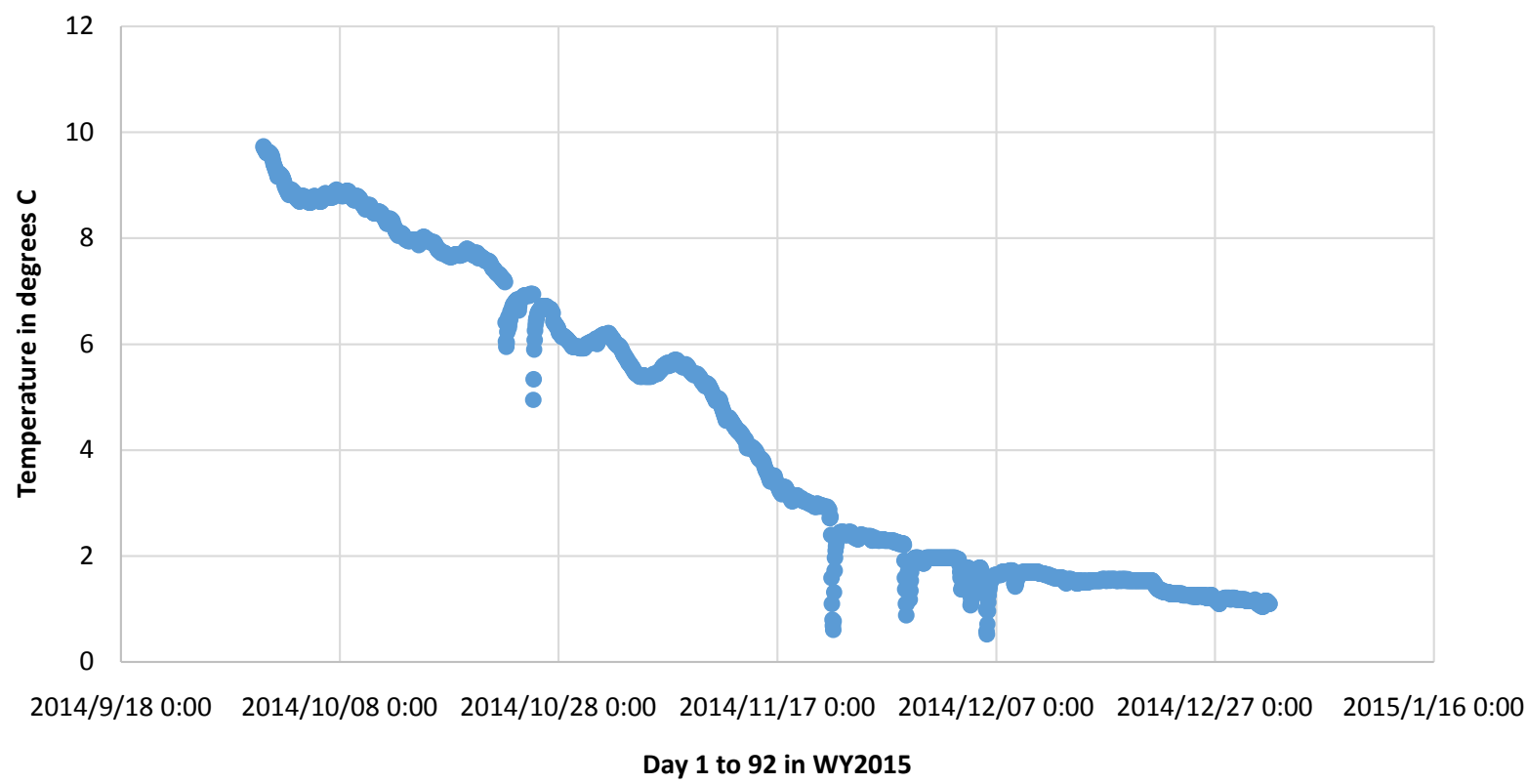

Figure 15. Temperature recorded every 60 minutes at $50 \mathrm{~cm}$ depth using Hobo U23 Pro v2 temperature/relative humidity data loggers during the months of October, November, and December in WY2015. Each negative deflection is associated with a rain event recorded at Chemult Alternate SNOTEL Site (http://www.wcc.nrcs.usda.gov/nwcc/site?sitenum=395). After 8-December freezing of the ground surface around the PVC pipe apparently stopped cold rain water from moving downward to the depth of the temperature probe.

depth (15-March) and the highest ground temperature on 1-June (Table 4).

\section{Discussion}

The occurrence of groundwater and the flow pathways it follows in volcanic rocks are controlled by structure, the stratigraphy and physical properties of volcanic units and associated volcaniclastic sedimentary deposits, and the geomorphologic evolution of the volcanic landscape. Examples of the complexities that arise in volcanic systems are described throughout the world (e.g. [17] [18] [19]). In the study area, the blanket of Plinian fall overlying relatively low permeability bedrock units [12] reduces these complexities and allows examination of the system response to annual fluctuations in the amount and form of winter precipitation. Thus, the perched, unconfined pumice aquifer provides insight into processes under predicted climate change scenarios in the western United States [2] [3] [4] [5].

The eruption of Mount Mazama mantled the low relief landscape of the study area with approximately $3 \mathrm{~m}$ of pumice. The aquifer that developed in the pumice layer is relatively isotropic, but has been modified 1) by erosion followed by deposition of alluvium in flat-bottomed ephemeral stream valleys, 2) by erosion followed by lacustrine sedimentation in areas where shallow lakes ponded shortly after the eruption, 3) by erosion followed by peat and organic-rich sediment accumulation in fen environments, and 4) by iron oxide precipitation 
within the aquifer that locally restricted lateral flow [10].

The expected annual pattern of snow accumulation during winter months, rapid springtime melting and recharge of the pumice aquifer, and discharge by evapotranspiration during the summer growing season did not occur in WY2015 when winter precipitation fell primarily as rain. Recharge of the pumice aquifer in WY2015 (Figures 3-6) when cumulative precipitation was above average (Figure 14) was similar to WY2014 (Figure 16) when, for the same time period, cumulative precipitation was near record lows. A measure of recharge and discharge from the aquifer is provided by change in storage expressed as percent of the total thickness (pumice only sites or pumice plus overlying sediments sites) saturated at the start of each water year (1-October) and on 1-June (Table 5). This measure is imperfect because storage decreased after the start of the water year as indicated by increased depth to water table before the onset of autumn precipitation. Likewise, 1-June measurements reflect the state of the system under different ground temperatures at $50 \mathrm{~cm}$ depth and vegetation growth. Because of these relations, the percent saturated thicknesses presented in

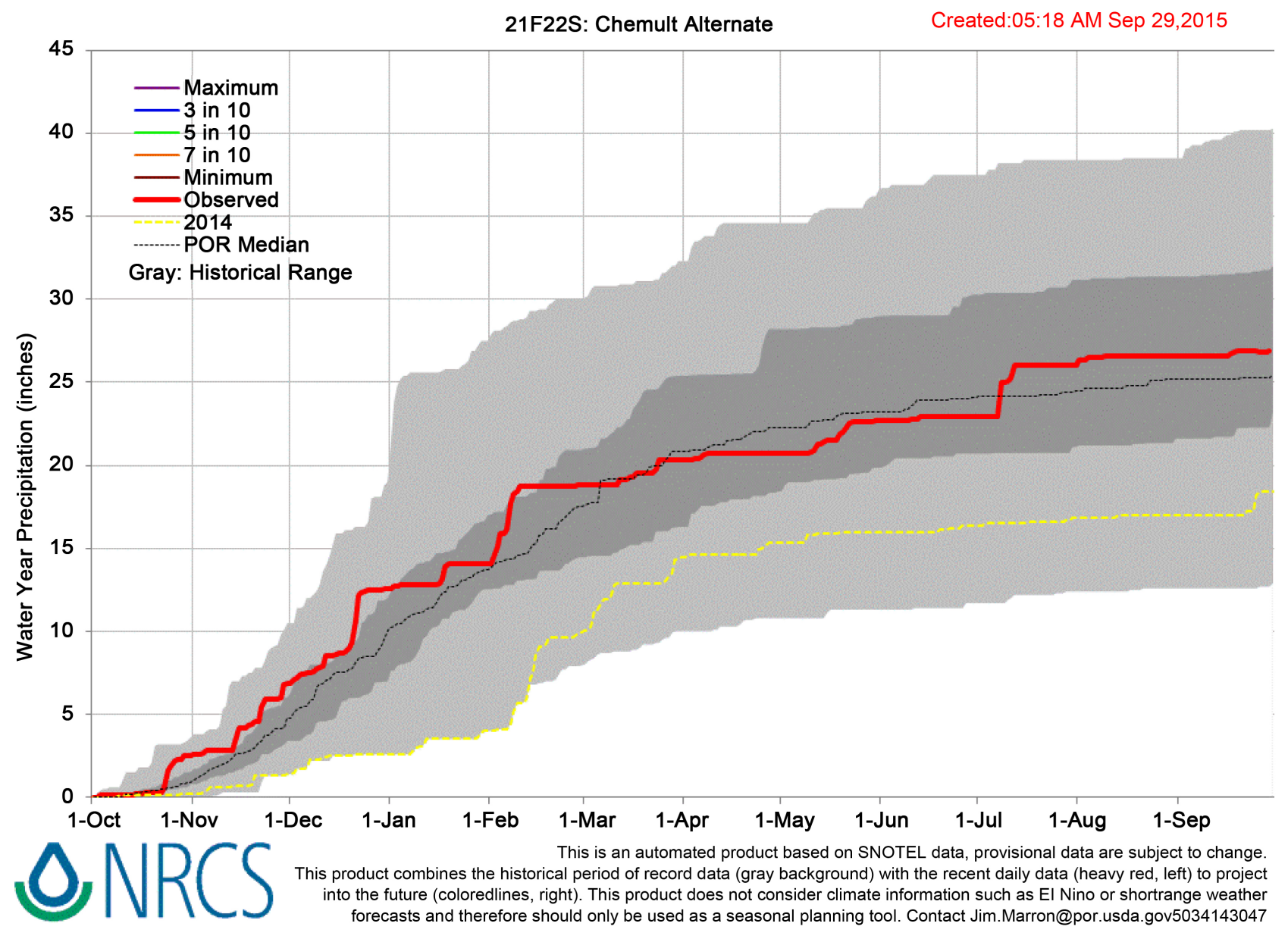

Figure 16. Cumulative precipitation curves for WY2014 (dashed yellow) and WY2015 (solid red) compared to the period of record (1981-2015) median, and historical ranges for the Chemult Alternate SNOTEL station 395

(http://www.wcc.nrcs.usda.gov/nwcc/site?sitenum=395). 
Table 5. Percent of aquifer thickness saturated at the start of the water year and on 1-June for representative piezometers in Figures 3-6. Recession rates of the water table in $\mathrm{cm}$ /day are included for each piezometer.

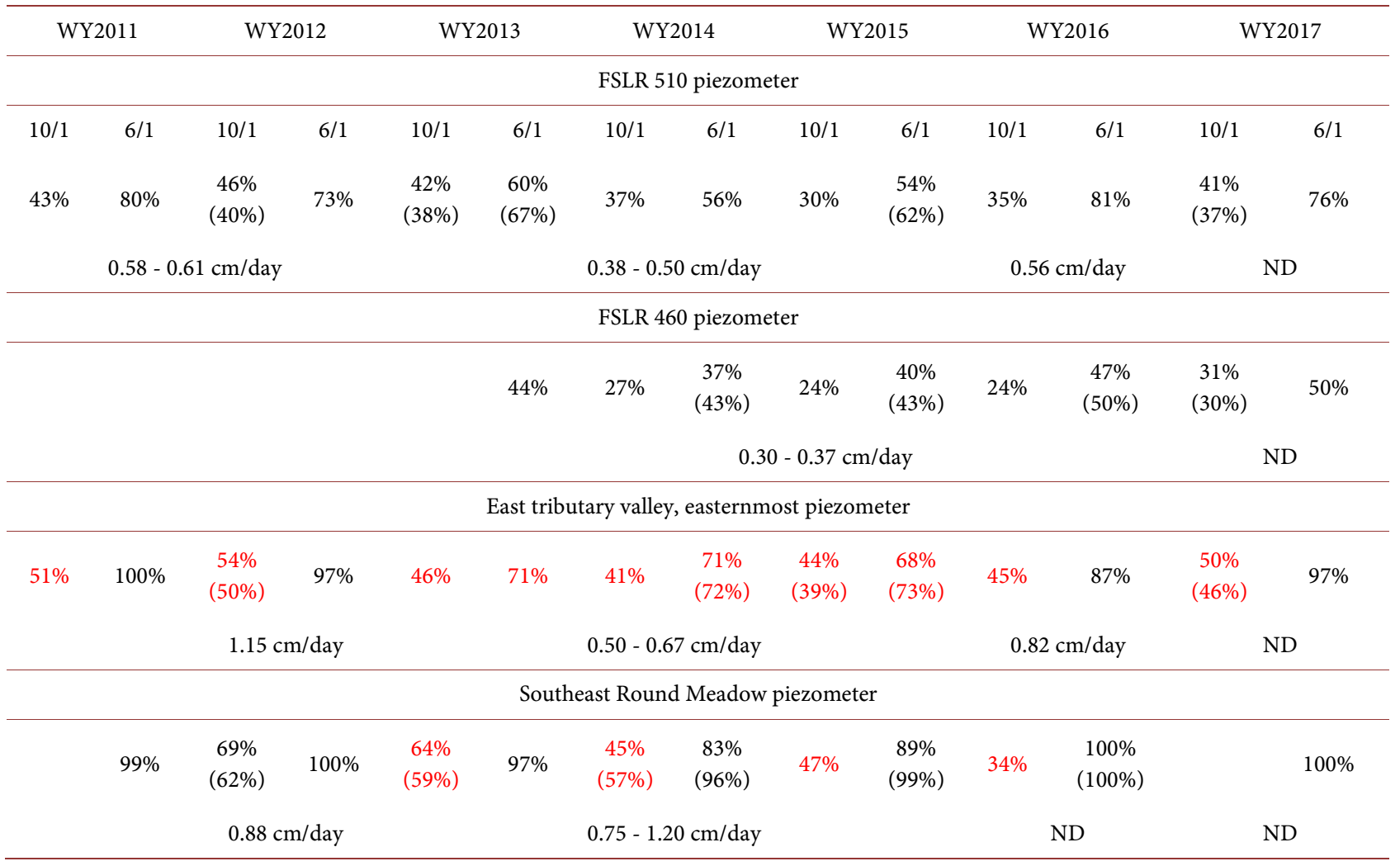

Percentages in parentheses are saturated thickness on dates in October after the start of the water year and on dates in April or May. Highlighted percentages (red) for the east tributary valley and southeast Round Meadow piezometers indicate the water table was within the pumice layer beneath either alluvium or lacustrine sediments on the date of measurement. $\mathrm{ND}=$ not determined.

Table 5 are minimum values for recharge and discharge. Where, available, maximum and minimum values for dates other than 30-September and 1-June are indicated in parentheses in Table 5. Table 5 also contains water table recession rates in $\mathrm{cm} /$ day. Years when the water table was deeper on 1-June have lower recession rates than water years when the 1-June water table was near surface.

In this discussion, we will consider the inter-annual variations in storage in the pumice aquifer in relation to precipitation patterns. The focus will be on three water years; 1) WY2013, 2) WY2014, a year of severe drought, and 3) WY2015 when winter precipitation was rain dominated. This is followed by discussion of rain- versus snow-dominated winter precipitation in this landscape.

\subsection{WY2013}

Water year 2013 was the first of three water years when SWE was zero and the percentage of annual precipitation received was below $80 \%$ on 1 -April. This water year was preceded by two water years when annual precipitation was above the 30-year average (Table 1), herein designated "wet" years. These water years, 
2011-2012, were characterized by a strong La Niña. However, WY2013 experienced drought conditions that persisted to the south in California between 2011 and 2015 [20]. The first site visits were on 26-27-April when it was observed that the stream network was dry and there was no evidence of flow in these channels during the freshet. Discharge on Jack Creek at FSCR 8821 was $0.87 \mathrm{~m}^{3} \cdot \mathrm{s}^{-1}$ and the channel was dry by 7-July (Table 3 ).

Sixteen (16) percent of the annual precipitation fell during the last six months of WY2012 (Table 1). The dry summer depleted groundwater storage in the aquifer below levels in the previous "wet" years. Although the impact on storage was not great, a few percent of aquifer thickness (Table 5), lower storage at the start of the water year combined with less springtime recharge produced declines in storage in each of the following water years through the start of WY2016 (end of WY2015). This is particularly noted at sites where remnants of the pumice aquifer are overlain by alluvium (e.g. east tributary valley, Figure 5) and to a lesser extent at sites where the pumice aquifer is exposed at the surface (e.g. FSLR 510, Figure 3). Deeper water tables on 1-June, characteristic of WY2013 and the following two years, are associated with lower recession rates during the growing season (Table 5). Early snow melt (SWE $=0$ on 1 -April, Table 1 ) was reflected in warming of the ground at $50 \mathrm{~cm}$ (Table 4) four to six weeks earlier than warming in "wet" years (Table 4). Earlier warming is noted in the three years when SWE $=0$ on 1-April. However, this pattern persisted in subsequent water years when snow cover remained after 1-April (WY2016 and WY2017; Table 4). This is particularly noted in WY2017 when 87 percent of the annual precipitation had fallen by 1-April, precipitation was $23 \mathrm{~cm}$ above the 30 -year average, and winter precipitation fell mainly as snow (Table 1).

In fen environments, groundwater levels peripheral to the main area of upflow experienced declines in water levels (Figure 9). However, in these peripheral areas the water table remained near surface within the confining peat layers throughout the growing season. Within the prominent up flow zones and at lower elevations within the fens the potentiometric surface remained above the ground surface as indicated for the W6-1.4 piezometer at the Wilshire fen (Figure 9).

\subsection{WY2014, a Severe Drought Year}

WY2014 was the third driest year on record at the Chemult Alternate SNOTEL Site. During that water year the severe drought conditions experienced in California extended northward into the study area. The cumulative precipitation curve for the Chemult Alternate SNOTEL Site persisted at record low values between the start of the water year and about the middle of February (Figure 16). The annual precipitation was only $46.7 \mathrm{~cm}$ and SWE was zero and $79 \%$ of precipitation was received by 1 -April (Table 1). Neither evidence of flow nor local ponding in depressions during the freshet was found in the ephemeral stream network. In the perennial reaches of Jack Creek and Sellers Creek dis- 
charge was low on 1-June. At the FSCR 8821 culvert on Jack Creek discharge was too low to measure in the culvert and discharge was estimated at $0.12 \mathrm{~m}^{3} \cdot \mathrm{s}^{-1}$ at an improvised measurement site (Table 3 ). The creek was dry at this location on 7-July-2014. Discharge at FSCR 9405 on Sellers Creek was $8 \times 10^{-3} \mathrm{~m}^{3} \cdot \mathrm{s}^{-1}$ on 14-June and decreased to $1.2 \times 10^{-3} \mathrm{~m}^{3} \cdot \mathrm{s}^{-1}$ by 14 -September. As in WY2013, the water table at locations where alluvium covered remnants of the Plinian pumice fall was within the pumice layer beneath the rooting zone of most plants and recession rates persisted at lower rates during the growing season (Table 5). Forage in meadows was stunted and sparse. In some fens, bryophytes turned brown and deep $(\sim 30 \mathrm{~cm})$ desiccation cracks developed in the peat confining layer ([9], Figure 13 therein).

\subsection{WY2015, Winter Precipitation Dominated by Rain}

The study area followed precipitation patterns throughout the western United States where there was exceptionally low snowpack in WY2015 [20]. Although precipitation received at the Chemult Alternate SNOTEL Site was above the 30 year average until late February (Figure 14), snow cover was minimal in January (Figure 13(b)), SWE was zero on 1-April, and 76 percent of annual precipitation had been received by 1 -April (Table 1 ). The rain-dominated winter precipitation foreshadows climate change scenarios for the Pacific Northwest [2] [4] [5]. Although winter access to the study area in most years was by snow machines, in WY2015 access by sports utility vehicles was possible throughout the winter (Figure 11), but was restricted during the spring thaw when frost was coming out and roads constructed with native material (pumice) were impassable. Our first visit was 7-March-2015 when access was possible during the morning when the roads were still frozen.

Although precipitation, mainly as rain, was greater than the 30 -year average during the first 4.5 months of the water year, storage in the pumice aquifer on 1-June was similar to storage on 1-June in WY2014 when record low precipitation was received as snow during the same time span (Table 5). Likewise, stream discharge for Jack Creek at FSCR 8821 was $0.18 \mathrm{~m}^{3} \cdot \mathrm{s}^{-1}$ on 1-June-2015 compared to $0.12 \mathrm{~m}^{3} \cdot \mathrm{s}^{-1}$ on 1 -June-2014. This stands in stark contrast to cold season discharge at this site on 23-December-2014 and 21-January-2015 estimated at 3.0 to $3.5 \mathrm{~m}^{3} \cdot \mathrm{s}^{-1}$ and $0.9 \mathrm{~m}^{3} \cdot \mathrm{s}^{-1}$, respectively (Table 3 ). Stream flow during winter months in WY2015 removed water from the catchments that in most years would have been stored in snowpack until the freshet. The commonly observed pattern of relatively rapid melting of snow pack in late February-early March with, in "wet" years, widespread inundation of low lying areas did not occur. As a result, recharge of the pumice aquifer was limited, stream-flow on 1-June-2015 was low, low water tables stressed bryophyte-dominated vegetation in the fens, produced deep desiccation cracks for the second year, and sparse forage in meadows. In WY2015 as well as in WY2014, water was hauled in to support cattle grazing. Discharge from springs in Round Meadow was approximately 50\% 
at the end of WY2015 of the discharge at the end of WY2014 [10].

\subsection{Rain versus Snow and Recharge of the Pumice Aquifer}

The rain-dominated winter of WY2015 in the study area coincided with snow drought in the western United States. Snow records west of $115^{\circ} \mathrm{W}$ for 1 -April found the lowest ever recorded SWE at $81 \%$ of stations with at least 40 years of record [20]. Mote et al. [20] argued that human influence and sea surface temperature anomalies contributed to the snow drought in Oregon and Washington. Cooper et al. [3] tested whether the sensitivity of Cascades snowpacks during this snow drought could serve as an analog for climate warming. They reported the 2014 and 2015 winter air temperature anomalies were approximately $+2^{\circ} \mathrm{C}$ and $+4^{\circ} \mathrm{C}$, respectively, above the climatological mean. By comparing model predictions to field based observations they concluded that only the modeled basin-mean peak SWE resembled predicted values based on modeled sensitivities. They concluded that magnitude and phasing of winter precipitation events rather than just air temperature controlled date of peak SWE, duration of snow cover, and snow disappearance date.

Although changing climate in the Pacific Northwest is expected to produce shifts toward less snow, more rain, and early snowmelt [2] [4] [5] the analysis of Cooper et al. [3] raises important factors that contribute to changes in system dynamics in the Cascades. Our study area lies in the rain shadow of the Cascades Range. The elevation (1590 to $1760 \mathrm{~m}$ ) is higher than most pass elevations in the Cascades Range, but its location in the rain shadow results in significantly less total precipitation and colder air temperatures. These differences are reflected in oxygen-hydrogen isotopic ratios for precipitation in the Cascades versus the highlands that lie east of the Cascades crest [10] [21].

The three water years marked by zero SWE on 1-April at the Chemult Alternate SNOTEL Site, relatively lower recharge of the pumice aquifer, and the lowest storage at the end of the water year are different in terms of snow- versus rain-dominated winter precipitation. In WY2013 and WY2014 the annual precipitation was below the 30-year average, but fell primarily as snow. Low recharge of the aquifer during the freshet was related to low snow pack. In WY2015, winter precipitation was above the 30-year average through much of the winter, but primarily as rain. Stream flow leaving the upper Jack Creek basin in December and January (Figure 11) removed water that would normally have been stored in snowpack until the freshet. Data from our instrument station located in the study area suggests early winter rain-dominated storms followed by freezing temperatures produced frozen ground that limited infiltration and encouraged runoff. By the middle of December, 2014, the ground had frozen as suggested by the deflections noted in temperature records at $50 \mathrm{~cm}$ depth (Figure 15) and field observations (T. Simpson, written communication, 31-December-2014; 23-January-2015) and remained so into early March when the frost was coming out of native material roads. Thus, the above average precipitation until roughly 
1-March during WY2015 (Figure 14) produced recharge and recession rates that were similar to the severe drought year of WY2014.

Potentially, climate change scenarios of more frequent snow- and rain-dominated and rain-dominated winters [2] [4] [5] will stress this perched, near-surface source of groundwater in the rain shadow of the Cascades Range. The pattern of storms starting as rain and turning late to snow and ground-freezing temperatures leads to runoff during the next rain-dominated precipitation event. These patterns suggest an increasing number of years with winter stream flow in channels that are currently dry, reduced near-surface groundwater storage in the pumice aquifer because of increased winter time runoff, muted springtime freshet similar to "dry" water years like WY2013 and WY2014, and more frequent stressing of groundwater-dependent ecosystems, forage in meadows, and forest health (e.g. [22]).

\section{Conclusions}

Groundwater storage in the unconfined and partially confined pumice aquifer follows annual precipitation patterns with the maximum storage following the spring freshet and minimum storage near the end of the water year and start of the next water year.

The highest recession rates of the water table occurred where alluvium overlies the partially eroded pumice aquifer and the water table on 1-June was within the rooted zone. Lower recession rates were noted where the 1-June water table was within the pumice aquifer but below the main rooting zone for most plants. Lower recession rates were noted in "dry" years when the 1-June water table was deeper in the pumice aquifer than in "wet" years when the 1-June water table was near the surface.

Water years characterized by deeper water tables on 1-June received less than $80 \%$ of precipitation by 1-April and had zero SWE on 1-April.

Maximum storage and change in storage during the growing season in the pumice aquifer following the rain-dominated precipitation pattern of WY2015 was similar to patterns observed in the "dry" water years of WY2013 and WY2014 even though total precipitation was near the 30-year average.

Rain-dominated winter storms followed by cold temperatures in WY2015 produced freezing of the ground surface and contributed to runoff during the winter months. The lack of water storage in snowpack contributed to weak recharge of the pumice aquifer during the freshet, anomalously low stream flow on 1-June, and deep water tables throughout the growing season. These factors contributed to drying of peat layers and local desiccation in fens, reduced forage in meadows, and reduced discharge from springs. Similar patterns were observed in the severe drought of WY2014.

\section{References}

[1] Danner, A.G., Safeeq, M., Grant, G.E., Wickham, C., Tullows, D. and Santelmann, 
M.V. (2017) Scenario-Based and Scenario-Neutral Assessment of Climate Change Impacts on Operational Performance of a Multipurpose Reservoir. Journal of the American Water Resources Association (JAWRA), 53, 1467-1482. https://doi.org/10.1111/1752-1688.12589

[2] Safeeq, M., Shukla, S., Arismendi, I., Grant, G.E., Lewis, S.L. and Nolin, A. (2016) Influence of Winter Season Climate Variability on Snow-Precipitation Ratio in the Western United States. International Journal of Climatology, 36, 3175-3190. https://doi.org/10.1002/joc.4545

[3] Cooper, M.G., Nolin, A.W. and Safeeq, M. (2016) Testing the Recent Snow Drought as an Analog for Climate Warming Sensitivity of Cascades Snowpacks. Environmental Research Letters, 11, Article ID: 084009. https://doi.org/10.1088/1748-9326/11/8/084009

[4] Hamlet, A.F. (2011) Assessing Water Resources Adaptive Capacity to Climate Change Impacts in the Pacific Northwest Region of North America. Hydrology and Earth System Science, 15, 1427-1443. https://doi.org/10.5194/hess-15-1427-2011

[5] Vano, J.A., Nijssen, B. and Lettenmaier, D.P. (2015) Seasonal Hydrologic Responses to Climate Change in the Pacific Northwest. Water Resources Research, 15, 1959-1976. https://doi.org/10.1002/2014WR015909

[6] Garcia, E.S. and Tague, C.L. (2015) Subsurface Storage Capacity Influences Climate-Evapotranspiration Interaction in Three Western United States Catchments. Hydrology and Earth System Sciences, 19, 4845-4858. https://doi.org/10.5194/hess-19-4845-2015

[7] Bacon, C.R. and Lanphere, M.A. (2006) Eruptive History and Geochronology of Mount Mazama and the Crater Lake Region, Oregon. Geological Society of America Bulletin, 118, 1331-1359. https://doi.org/10.1130/B25906.1

[8] Young, S.R. (1990) Physical Volcanology of Holocene Airfall Deposits from Mt. Mazama, Crater Lake, Oregon. Ph.D. Dissertation, University of Lancaster, Lancaster.

[9] Cummings, M.L., Weatherford, J.M. and Mowbray, L.A. (2014) Hydrogeology of Pumice-Hosted Fens in the Winema-Fremont National Forest, Oregon, USA. Journal of Water Resource and Protection, 6, 1762-1780. https://doi.org/10.4236/jwarp.2014.619158

[10] Weatherford, J.M. and Cummings, M.L. (2016) Ground- and Surface-Water Interactions of a Pumice Aquifer in a Headwaters Watershed: Round Meadow, Fremont-Winema National Forest, Oregon, USA. Journal of Water Resource and Protection, 8, 1010-1034. https://doi.org/10.4236/jwarp.2016.811081

[11] Aldous, A.R., Gurrieri, J.T., Bach, L.B., Congdon, R.D., Carlson, C.P., Carroll, T.A. and Nevill, M. (2014) A Groundwater Balancing Act: Environmental Flows and Levels for Groundwater-Dependent Fens of the Antelope Grazing Allotment, Fremont-Winema National Fores, Oregon. The Nature Conservancy and the USDA Forest Service, Portland.

[12] Gusey, D.L. (2010) Drilling Report Antelope Groundwater Monitoring Wells Chemult Ranger District-Fremont-Winema National Forest, September 29-October 4, 2010. Internal Report Fremont-Winema National Forest, Oregon.

[13] Weatherford, J.M. (2015) Hydrogeologic Investigation of a Pumice Aquifer, Fremont/Winema National Forest, Oregon. M.Sc. Thesis, Portland State University, Portland.

[14] Klug, C., Cashman, K.V. and Bacon, C.R. (2002) Structure and Physical Characteristics of Pumice from the Climactic Eruption of Mount Mazama (Crater Lake), 
Oregon. Bulletin of Volcanology, 64, 486-501.

https://doi.org/10.1007/s00445-002-0230-5

[15] Aldous, A.R. and Bach, L. B. (2014) Hydro-Ecology of Groundwater-Dependent Ecosystems: Applying Basic Science to Groundwater Management. Hydrological Sciences Journal, 59, 530-544. https://doi.org/10.1080/02626667.2014.889296

[16] Aldous, A. and Gurrieri, J.(2011) Environmental Flows and Levels for Groundwater-Dependent Fens of the Antelope Grazing Allotment, Fremont-Winema National Forest, Oregon. Internal Report Chemult Range District, Fremont-Winema National Forest, Oregon.

[17] Mende, A., Astorga, A. and Neumann, D. (2007) Strategy for Groundwater Management in Developing Countries: A Case Study in Northern Costa Rica. Journal of Hydrology, 334, 109-124. https://doi.org/10.1016/j.jhydrol.2006.10.016

[18] Ayenew, T., Demlie, M. and Wohnlich, S. (2008) Hydrogeological Framework and Occurrence of Groundwater in the Ethiopian Aquifers. Journal of African Earth Sciences, 53, 97-113. https://doi.org/10.1016/j.jafrearsci.2008.06.006

[19] Morgenstern, U., van der Raaij, R. and Baalousha, H. (2012) Groundwater Flow Pattern in the Ruataniwha Plains as Derived from the Isotope and Chemistry Signature of the Water. Report No. 2012/23, GNS Science Report, Lower Hutt.

[20] Mote, P.W., Rupp, D.E., Li, S., Sharp, D.J., Otto, F., Uhe, P.F., Xiao, M., Lettenmaier, D.P., Cullen, H. and Allen, M.R. (2016) Perspectives on the Causes of Exceptionally Low 2015 Snowpack in the Western United States. Geophysical Research Letters, 43, 10980-10988. https://doi.org/10.1002/2016GL069965

[21] Palmer, C.P., Gannett, M.W. and Hinkle, S.R. (2006) Isotopic Characteristics of Three Groundwater Recharge Sources and Inferences for Selected Aquifers in the Upper Klamath Basin of Oregon and California, USA. Journal of Hydrology, 336, 17-29. https://doi.org/10.1016/j.jhydrol.2006.12.008

[22] Coops, N.C. and Waring, R.H. (2011) A Process-Based Approach to Estimate Lodgepole Pine (Pinus contorta Dougl.) Distribution in the Pacific Northwest under Climate Change. Climate Change, 105, 313-328.

https://doi.org/10.1007/s10584-010-9861-2 